University of South Florida

DIGITAL COMMONS

Digital Commons @ University of

@ UNIVERSITY OF SOUTH FLORIDA

South Florida

$10-2019$

\title{
Mechanisms of Organic Matter Export in Estuaries with Contrasting Carbon Sources
}

\author{
A. R. Arellano \\ University of South Florida, aarellan@usf.edu \\ T. S. Bianchi \\ University of Florida \\ C. L. Osburn \\ North Carolina State University \\ E. J. D'Sa \\ Louisiana State University and Agricultural and Mechanical College \\ N. D. Ward \\ University of Florida
}

See next page for additional authors

Follow this and additional works at: https://digitalcommons.usf.edu/msc_facpub

Part of the Life Sciences Commons

\section{Scholar Commons Citation}

Arellano, A. R.; Bianchi, T. S.; Osburn, C. L.; D'Sa, E. J.; Ward, N. D.; Oviedo-Vargas, D.; Joshi, I. D.; Ko, D. S.; Shields, M. R.; Kurian, G.; and Green, J., "Mechanisms of Organic Matter Export in Estuaries with Contrasting Carbon Sources" (2019). Marine Science Faculty Publications. 1445.

https://digitalcommons.usf.edu/msc_facpub/1445

This Article is brought to you for free and open access by the College of Marine Science at Digital Commons @ University of South Florida. It has been accepted for inclusion in Marine Science Faculty Publications by an authorized administrator of Digital Commons @ University of South Florida. For more information, please contact digitalcommons@usf.edu. 


\section{Authors}

A. R. Arellano, T. S. Bianchi, C. L. Osburn, E. J. D'Sa, N. D. Ward, D. Oviedo-Vargas, I. D. Joshi, D. S. Ko, M. R. Shields, G. Kurian, and J. Green 


\section{JGR Biogeosciences}

\section{RESEARCH ARTICLE 10.1029/2018JG004868 \\ Mechanisms of Organic Matter Export in Estuaries with Contrasting Carbon Sources}

\section{Special Section:}

Carbon Cycling in Tidal Wetlands and Estuaries of the Contiguous United States

Key Points:

- Marsh organic matter sources are dominant in Barataria Bay due to a lack of direct river inputs and high relative sea level rise

- Dissolved lignin export was 5 times greater than particulate in Apalachicola Bay, suggesting rivers are driving a large export of dissolved organic matter

- Particulate lignin export was 5 times greater than dissolved in Barataria Bay suggesting coastal marsh erosion is driving a large export of particulate organic matter

Supporting Information:

- Supporting Information S1

- Table S1

- Table S2

- Table S3

- Table S4

Correspondence to:

A. R. Arellano,

aarellan@mail.usf.edu

Citation:

Arellano, A. R., Bianchi, T. S., Osburn, C. L., D'Sa, E. J., Ward, N. D., OviedoVargas, D., et al. (2019). Mechanisms of organic matter export in estuaries with contrasting carbon sources. Journal of Geophysical Research: Biogeosciences, 124, 3168-3188. https://doi.org/10.1029/ 2018JG004868

Received 4 FEB 2019 Accepted 28 AUG 2019

Accepted article online 30 SEP 2019

Published online 31 OCT 2019

(C)2019. American Geophysical Union. All Rights Reserved.

\author{
A. R. Arellano ${ }^{1,2}$ (D) T. S. Bianchi ${ }^{1}$ iD, C. L. Osburn ${ }^{3}$ iD, E. J. D'Sa ${ }^{4}$ iD, N. D. Ward ${ }^{1,5,6}$ (iD, \\ D. Oviedo-Vargas ${ }^{3,7}$ iD, I. D. Joshi ${ }^{4}$ iD, D. S. Ko ${ }^{8}$ iD, M. R. Shields ${ }^{1}$ iD, G. Kurian' ${ }^{1}$, and J. Green ${ }^{1}$ \\ ${ }^{1}$ Department of Geological Sciences, University of Florida, Gainesville, FL, USA, ${ }^{2}$ College of Marine Science, University of \\ South Florida Saint Petersburg, Saint Petersburg, FL, USA, ${ }^{3}$ Department of Marine Earth and Atmospheric Sciences, \\ North Carolina State University, Raleigh, NC, USA, ${ }^{4}$ Department of Oceanography and Coastal Sciences, Louisiana State \\ University and Agricultural and Mechanical College, Baton Rouge, LA, USA, ${ }^{5}$ Marine Sciences Laboratory, Pacific \\ Northwest National Laboratory, Sequim, WA, USA, ${ }^{6}$ School of Oceanography, University of Washington, Seattle, WA, \\ USA, ${ }^{7}$ Stroud Water Research Center, Avondale, PA, USA, ${ }^{8}$ Oceanography Division, Naval Research Laboratory, Stennis \\ Space Center, MS, USA
}

Abstract Modifications in land use and climate will result in shifts in the magnitude and composition of organic matter $(\mathrm{OM})$ transported from wetlands to coastal waters, but differentiation between riverine and wetland OM sources in coastal areas remains a challenge. Here, we evaluate particulate and dissolved $\mathrm{OM}$ export dynamics in two representative estuary geomorphologies-Apalachicola Bay (AP) and Barataria Bay (BB), characterized primarily by blackwater river inputs and high particle abundance, respectively. The magnitude and composition of OM exported from each estuary was evaluated based on seasonal measurements of surface water dissolved organic carbon (DOC), particulate organic carbon (POC), particulate nitrogen, the stable isotopic composition of DOC and POC, dissolved and particulate lignin phenols, and carbon-normalized dissolved lignin-phenol yields. Data and discriminant analyses support the initial hypothesis; AP is dominated by a more terrestrial source of OM due to importance of fluvial dissolved $\mathrm{OM}$ inputs, while $\mathrm{BB}$ is a more particle-rich and wetland carbon-dominated system. Total lignin export (sum of mean dissolved and mean particulate) was higher in $\mathrm{BB}\left(5.73 \pm 2.50 \times 10^{5} \mathrm{~kg} / \mathrm{year}\right)$ than in $\mathrm{AP}$ $\left(4.21 \pm 2.35 \times 10^{5} \mathrm{~kg} /\right.$ year $)$. Particulate lignin export from BB was greater than the export of dissolved lignin at either BB or AP, suggesting coastal marsh erosion may be driving this comparatively large export of particulate lignin. These data have important implications for the stability of stored OM in coastal habitats, particularly since such habitats in this region are highly vulnerable due to relative sea level rise.

\section{Introduction}

Carbon cycling dynamics across land-water interfaces such as estuaries have been shown to be controlled by a diversity of physical drivers (e.g., wave and tidal energy, particle dynamics, residence time, riverine inputs, and light availability; Bianchi et al., 2004; Chanton \& Lewis, 2002; Childers \& Day, 1990; Kemp \& Boynton, 1984). Some of these interfaces within the aquatic continuum, characterized by even steeper gradients largely derived from human perturbations, have been described as aquatic critical zones (Bianchi \& Morrison, 2018). The biogeochemical cycling of estuaries around the world has been severely impacted by humans (e.g., land use change, damming, eutrophication, and sea level rise) in the Anthropocene. For example, the dynamics of estuarine dissolved and particulate organic carbon (DOC and POC), known to be largely controlled by the cycling of autochthonous (e.g., phytoplankton, macroalgae, and seagrasses) and allochthonous (e.g., watershed vascular plants, bordering wetlands, river phytoplankton, and soil organic matter) inputs (Bauer \& Bianchi, 2011, and reference therein), have been altered by such global changes.

For example, Bianchi et al. (2009) showed the significance of wetland dissolved organic matter (DOM) loss in Louisiana to the coastal carbon cycle on the Louisiana shelf. In particular, Barataria and Terrebonne estuarine basins, within the Mississippi deltaic region, have experienced significant loss of wetlands and expansion of open-water habitat in response to subsidence due to the modification of regional hydrology by human perturbations (e.g., canal construction, damming in the watershed, river levees, and oil and gas extraction) as well as global effects (e.g., eustatic sea level rise). In fact, since 1930 the Mississippi River (MR) delta region has lost soil carbon at a rate of 1.86 to $3.12 \mathrm{Tg} /$ year (DeLaune \& White, 2012). 
Interestingly, these particle-rich estuaries, associated with the Mississippi deltaic complex, are seemingly divergent in character from other estuarine systems in the northern Gulf of Mexico (nGoM; at essentially the same latitude), along the panhandle of Florida, which are fed by high-DOC, low-particle rivers. Carbon export from estuaries as DOC has received much less attention than POC, though recent work has improved estimates along the eastern United States (Najjar et al., 2018). However, of the total organic carbon (OC) exported to the coastal ocean, DOC could comprise $>50 \%$ of the export (Adame \& Lovelock, 2011; Dame \& Allen, 1996; Dittmar et al., 2006; Happ et al., 1977; Twilley, 1985). None of these prior works has examined sources of organic matter (OM) export specifically due to the need for a multiproxy method with chemical biomarkers and isotopic signatures to examine the multiple sources of DOM and particulate organic matter $(\mathrm{POM})$ in coastal waters.

In this study, we compare the mechanisms of OM export from two divergent estuaries, Apalachicola Bay (AP) and Barataria Bay (BB), in the nGoM. AP is a shallow, subtropical, bar-built, and river-dominated estuary in northwestern Florida that has a hydraulic residence time of approximately 6 to 12 days (Dulaiova \& Burnett, 2008), blackwater riverine inputs, low suspended particle concentrations, and a relative sea level (RSL) rise of 1 to $2 \mathrm{~mm}$ /year (Tebaldi et al., 2012). In contrast, BB estuary is a broad shallow estuary within the MR delta complex that has a hydraulic residence time of approximately 30 days, little to no direct riverine inputs, and a RSL rise of approximately 8 to $10 \mathrm{~mm}$ /year (Blum \& Roberts, 2009). The primary goal of this study was to utilize the divergent character of two estuarine systems in the nGoM to examine pathways of OM export to the Gulf of Mexico (GoM) using total suspended solids (TSS), bulk POC, DOC, stable carbon isotopes $\left(\delta^{13} \mathrm{C}\right)$, and particulate and dissolved lignin phenols (chemical biomarker of vascular plants). We hypothesized that coastal wetlands constituted important sources of DOC and POC exported to the nGoM and also that the amount of wetland carbon in each pool was related to the loss of wetlands in each region. We also hypothesize the export of OC in BB will be dominated by POC, while in AP, the major loss is DOC.

\section{Materials and Methods}

\subsection{Site Description and Sample Collection}

AP is located in the panhandle of Florida (Figure 1a) and has a mean depth of $3 \mathrm{~m}$ and an area of $542 \mathrm{~km}^{2}$. The residence time of AP is one of the shortest among the estuaries in the GoM (Solis \& Powell, 1999). The Apalachicola and Carrabelle Rivers (AR and CR) feed into the northwestern and northeastern regions, respectively, of AP. The entire AP system is bound by four barrier islands (i.e, Dog Island, St. George Island, Little St. George Island, and St. Vincent Island) and tidal inlets (e.g., East Pass, Sikes Cut, West Pass, and Indian Pass) allowing for exchange to the GoM. The AR, which originates at the confluence of the Flint and Chattahoochee Rivers, provides $90 \%$ of the freshwater input to AP (Huang, 2010). In fact, the AR is the third largest river in the nGoM (Bianchi et al., 1999) and has the largest flow rate of Florida rivers (Mortazavi et al., 2000). The river's primary terrestrial OM source comes from longleaf pine in Apalachicola National Forest, the AR, and its unimpeded track from Jim Woodruff Dam to the GoM is called the Apalachicola River Blueway. The drainage basin of the AR is approximately 48,500 $\mathrm{km}^{2}$ (Livingston, 2013) and extends into Georgia. River flow is highly correlated with rainfall in Georgia, which peaks during late winter to early spring months (Meeter et al., 1979) and wanes during the late summer and early fall. Wetland vegetation in major creeks and marshes includes Nyssa sylvatica biflora (swamp tupelo), Taxodium distichum (bald cypress), and Sabal palmetto (cabbage palm; Anderson \& Lockaby, 2012). Common tree species in the watershed include Pinus clausa (sand pine), Pinus elliottii (slash pine), Quercus virginiana (live oak), and Cyrilla racemiflora (titi; Chelsea Nagy et al., 2012).

$\mathrm{BB}$ is a broad shallow estuary west of the MR associated with the highest historical land loss rates ( $\sim 77 \mathrm{~km}^{2} /$ year) in coastal Louisiana from 1978 to 2000 (Barras et al., 2003) due to sea level rise, subsidence, and construction of the man-made levee system along the MR (Penland et al., 2005; Figure 1b). The estuary is about $120 \mathrm{~km}$ long, with a water column salinity that is nearly homogeneous vertically, a tidal range of $0.35 \mathrm{~m}$ (near the mouth), and an average depth of $2 \mathrm{~m}$. The boundaries of BB are the levee of the MR to the east, the old channel of the MR to the west (Bayou Lafourche), and the GoM to the south. Two barrier islands (Grand Isle and Grand Terre) separate the estuary from the GoM. The northern half of the basin contains several large lakes. It no longer receives significant runoff and sediment load due to abandoned distributaries of the MR, and its freshwater inputs are from rainfall, stream runoff, man-made diversions, and the Gulf Intercoastal 

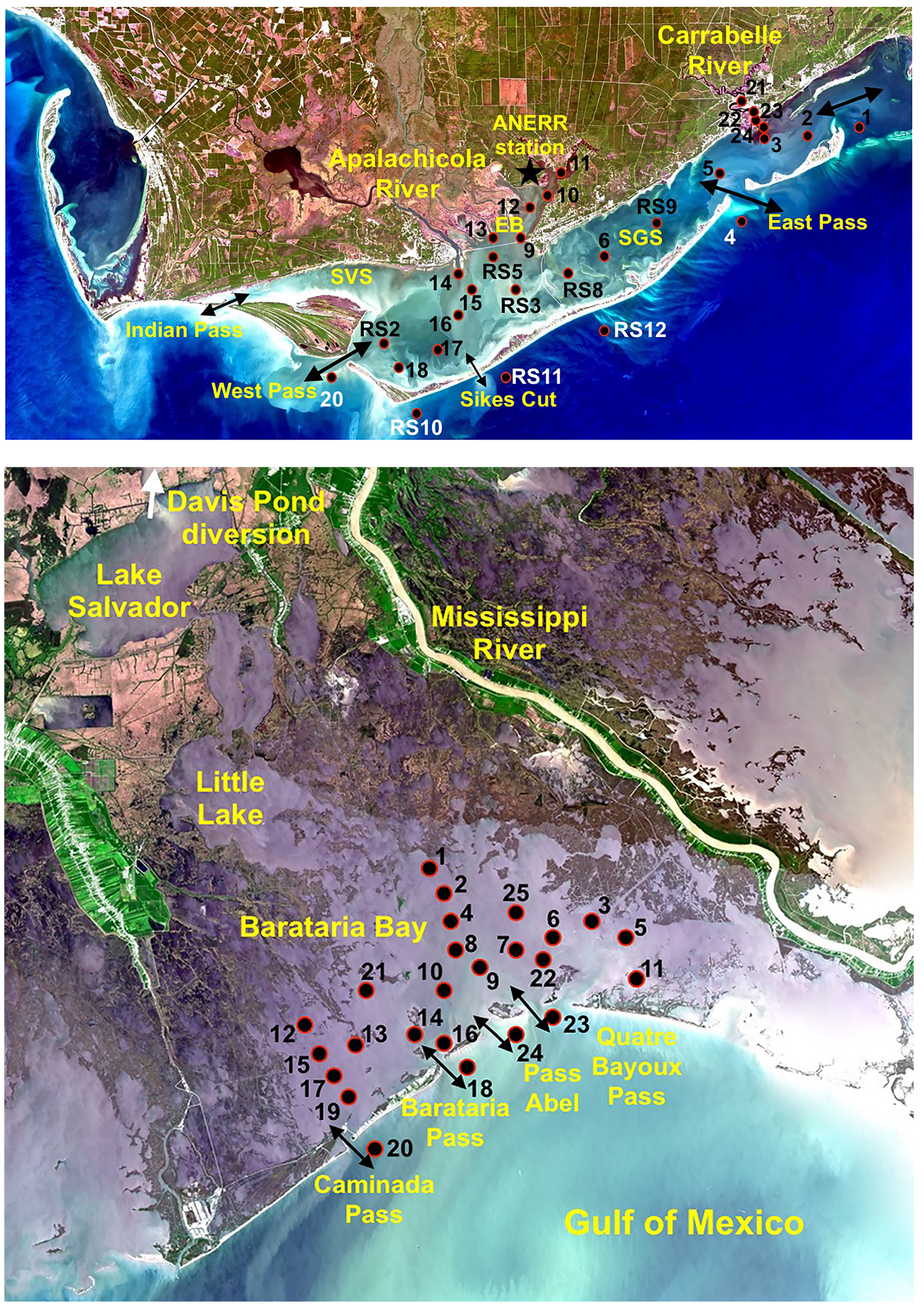

Figure 1. (a) Distribution of sampling sites for Apalachicola Bay, Florida (USA; modified from Joshi et al. 2017). (b) Distribution of sampling sites for Barataria Bay, Louisiana, USA. Arrows indicate cuts or passes used to calculate fluxes. Apalachicola National Estuarine Research Reserve (ANERR) Saint Vincent Sound (SVS), East bay (EB), and Saint George Sound (SGS). 
Waterway. However, there are small inputs of freshwater through the Naomi and West Pointe and la Hache siphons, along with the Davis Pond freshwater diversion, which was constructed in July 2002. It has a hydraulic residence time of approximately 30 days, although Solis and Powell (1999) calculated residence time of 140 days using the freshwater fraction method. In the winter, BB experiences strong northerly winds, while in the summer and fall it experiences weak southerly winds, and these seasonal winds can influence the residence times (Park, 2002; Reed, 1989). Wetland vegetation at BB includes, Juncus roemerianus (black rush), Spartina alteniflora (smooth cordgrass), Spartina cynosuroides (big cordgrass), Spartina patens (saltmeadow cordgrass), and Distichlis spicata (salt grass; Gosselink \& Pendleton, 1984; Visser et al., 1998)

Surface water samples were collected in AP (March 2015, July 2015, and November 2016) and in BB (July 2015, March 2016, and October 2016). Surface water samples were collected in 1- or 2-L bottles and stored on ice until filtration within $12 \mathrm{hr}$. Water samples were filtered through a preweighed and precombusted $\left(450^{\circ} \mathrm{C}\right.$ for $4 \mathrm{hr}$ ) $0.7-\mu \mathrm{m}$ nominal pore size glass fiber filter (Whatman GF/F; 47 and 25-mm diameter). Filtrate for dissolved lignin samples was kept frozen at $-20{ }^{\circ} \mathrm{C}$ in MilliQ+sample-rinsed dark high-density polyethylene resin (HDPE) bottles. DOC samples were filtered into precombusted 40-ml volatile organic compounds (VOC) vials with Teflon-lined septa caps in situ, acidified to $\mathrm{pH}<2$ using $40 \mu \mathrm{l}$ of $85 \%$ of phosphoric acid $\mathrm{H}_{3} \mathrm{PO}_{4}$ or $40 \mu \mathrm{l}$ of 6-N HCl. Filters for particulate lignin, $\mathrm{POC}$, particulate nitrogen, and $\delta^{13} \mathrm{C}$-POC analyses were kept frozen at $-20^{\circ} \mathrm{C}$ until further processing in the laboratory.

\subsection{Atmospheric and Hydrological Data}

Wind speed, wind direction, and water temperature were acquired from Apalachicola National Estuarine Research reserve at East Bay station for AP and from National Oceanic and Atmospheric Administration's National Data Buoy Center at Grand Isle for BB. The AR near Sumatra and Davis Pond Freshwater Diversion discharge were obtained from United States Geological Survey (USGS) water data record. AR water discharge was acquired from USGS water data archive (USGS 12359170; www.waterdata.usgs.gov).

\subsection{Analysis of DOC and POC}

DOC concentrations were measured on a Shimadzu TOC-V CSN analyzer equipped with an autosampler. High-temperature catalytic oxidation was used (Guo et al., 1994). Reported DOC concentrations are the mean of three to five replicate injections with a coefficient of variance of less than $2 \%$. Carbon standards were prepared using potassium hydrogen phthalate, and the instrument was calibrated using a five-point calibration curve. Instrument blank and DOC values were checked against reference low carbon deep seawater (Carbon Reference Materials, University of Miami, Rosenstiel School of Marine and Atmospheric Sciences) and $10 \mathrm{mg} \mathrm{C/L}$ standard (Ricca Chemical).

DOC samples were analyzed for carbon stable isotope values $\left(\delta^{13} \mathrm{C}\right.$-DOC) on an OI Analytical 1030D Aurora total organic carbon analyzer, using wet chemical oxidation, coupled via a trap and purge interface to a Thermo Delta V Plus isotope ratio mass spectrometer. Values were reported in standard delta notation using the following equation:

$$
\delta^{13} \mathrm{C}(\% \text { vs.VPDB })=\left[\left(\frac{R_{\text {sample }}}{R_{\text {standard }}}\right) \times 1,000\right]
$$

where, $\delta^{13} \mathrm{C}$ is the stable isotope value of carbon in parts per thousand, referenced to the Vienna Pee Dee Belemnite (VPDB) scale. $R_{\text {sample }}$ is the ${ }^{13} \mathrm{C}:{ }^{12} \mathrm{C}$ for the unknown sample, and $R_{\text {standard }}$ is the ${ }^{13} \mathrm{C}:{ }^{12} \mathrm{C}$ for the known standard (Osburn \& St Jean, 2007). $\delta^{13} \mathrm{C}$-DOC values were blank corrected and normalized to VPDB via a linear regression of six caffeine (International Atomic Energy Agency [IAEA]-600, $-27.7 \pm 0.04 \%$ ) and two sucrose (IAEA-C6, $-10.8 \pm 0.03 \%$ ) IAEA standards. Precision of $\delta^{13} \mathrm{C}-\mathrm{DOC}$ values is $\pm 0.4 \%$.

Frozen POM sample filters were freeze dried with a CHRIST alpha 1-4 plus bench top freeze dryer for 3 days. The filters were decarbonated via fumigation with 12-N HCL for $8 \mathrm{hr}$, dried for $12 \mathrm{hr}$ at $60{ }^{\circ} \mathrm{C}$ (Harris et al., 2001), and encased in silver capsules before POC elemental analysis. POM measurements were acquired with Thermo Electron DeltaV Advantage isotope ratio mass spectrometer coupled with a ConFlo II interface linked to a Carlo Erba NA 1500 CNS Elemental Analyzer. Samples were measured 
relative to laboratory reference $\mathrm{N}_{2}$ and $\mathrm{CO}_{2}$ gases. All $\delta^{13} \mathrm{C}$-POC results are expressed in standard delta notation relative to VPDB (Eq. (1)).

\subsection{Dissolved and Particulate Lignin Phenols}

DOM was extracted on hydrophilic-lipophilic balanced (HLB) cartridges according to the method of Keil and Neibauer (2009) and Arellano et al. (2018). CuO oxidation products were extracted and analyzed according to Hedges and Ertel (1982), as modified by Goñi and Hedges (1995) and further modified by Louchouarn et al. (2010). POM was collected on preweighed and precombusted GF/F filters (47-mm diameter, 0.7- $\mu$ m nominal pore size). The freeze-dried filter weight was recorded prior to cupric oxidation. Ethyl vanillin was quantitatively added after the oxidation step to be used as an absolute recovery standard. Lignin extracts were derivatized using N,O-bis (trimethylsilyl) trifluoroacetamide at $70{ }^{\circ} \mathrm{C}$ for $1 \mathrm{hr}$. Particulate and dissolved lignin oxidation products (LOPs) were analyzed with a Thermo Scientific Trace 1310 Gas Chromatograph coupled to a Thermo Scientific TSQ8000 Triple Quadrupole Mass Spectrometer fitted to an Equity-5 column (30-m length, $0.25-\mathrm{mm}$ internal diameter). A $1-\mu \mathrm{l}$ volume of the derivatized extract was injected into the split/splitless inlet which was operated in splitless mode and held constant at $260^{\circ} \mathrm{C}$. The oven temperature was held at $100{ }^{\circ} \mathrm{C}$, then ramped from $100-216^{\circ} \mathrm{C}$ at $4{ }^{\circ} \mathrm{C} / \mathrm{min}$, then ramped to $270{ }^{\circ} \mathrm{C}$ at $27^{\circ} \mathrm{C} / \mathrm{min}$, and held at $270{ }^{\circ} \mathrm{C}$ for $6 \mathrm{~min}$. Helium carrier gas was set to constant flow of $1.0 \mathrm{ml} / \mathrm{min}$. The transfer line and ion source temperatures were 280 and $250{ }^{\circ} \mathrm{C}$, respectively. Selected reaction monitoring was used to detect and quantify the compounds. Precursor ions, product ions, and collision energy used to quantify each compound are shown in supporting information Table S1. Relative response factors normalized to an analytical standard (methyl 3,4 dimethoxybenzoate) were calculated to account for instrument variability. The common practice is to work within the linear range of a triple quadrupole mass spec, but due to the wide range of concentrations needed to calibrate for LOP analysis, a logarithmic transformation was necessary for the calibration. Finally, LOP concentrations were corrected for loss during the extraction using the ethyl vanillin recovery standard. Samples with a recovery less than $60 \%$ were reextracted and reanalyzed for DOM. Recoveries were consistently low for POC ( $24 \%)$. Due to the availability of only one filter, POM samples were not reextracted and reanalyzed. Two internal recovery standards with different functional groups that represent the array of lignin phenol classes showed comparable recoveries. Thus, the composition of the lignin extracted likely represents the lignin composition in the POM. LOP parameters and diagnostic ratios were calculated according to Table S2. Concentrations of eight dissolved lignin phenols $\left(\Sigma_{8}\right)$, syringyl (S), vanillyl $(\mathrm{V})$, and cinnamyl $(\mathrm{C} ; \mu \mathrm{g} / \mathrm{L})$, carbon-normalized yields of $\Sigma_{8}\left(\Lambda_{8} ; \mathrm{mg} / 100 \mathrm{mg}\right.$ OC), carbonnormalized yields of sum of concentrations of $\mathrm{V}, \mathrm{S}, \mathrm{C}$, and $\mathrm{P}(\mathrm{mg} / 100 \mathrm{mg} \mathrm{OC})$, ratios of vanillic acid to vanillin phenols $(\mathrm{Ad}: \mathrm{Al})_{\mathrm{V}}$, ratios of syringic acid to syringaldehyde phenols $\left.(\mathrm{Ad}: \mathrm{Al})_{\mathrm{S}}\right)$, ratios of $p$-hydroxy benzoic acid to $p$-hydroxybenzaldehyde phenols $(\mathrm{Ad}: \mathrm{Al})_{\mathrm{P}}$, ratios of $\mathrm{S}$ to $\mathrm{V}(\mathrm{S}: \mathrm{V}), \mathrm{C}$ to $\mathrm{V}(\mathrm{C}: \mathrm{V}), 3$,5-dihydroxybenzoic acid (BD) to V (BD:V), and P to the sum of V and S (P: $[\mathrm{V}+\mathrm{S}])$. Prefixes "d" and "p" designate dissolved particulate OM, respectively. The low recovery for POM is likely a matrix effect from the Glass filter-F (GFF) filter dissolution in the 2- $\mathrm{N} \mathrm{NaOH}$ solution, which resulted in an immiscible phase during the liquid-liquid extraction with ethyl acetate. Although low recoveries were consistent for all samples, it is recommended that GF/F filters are not good for $\mathrm{CuO}$ oxidation in the future. POM recoveries are listed in Table S3.

\subsection{Statistical Analysis}

Randomization, which is a special case of Monte Carlo testing (Noreen, 1989), was used to test the significance of differences between AP and BB sample parameters by averaging the means of each bay and using the differences in parameter mean (delta means) as a test statistic. In the MATLAB computing environment (version 2015a), the "sort" and "rand" commands were used in a randomization process which was repeated 1,000 times, and delta means were calculated to generate a probability distribution and compute the $p$ value. To test the relationships between parameters, Pearson's linear correlation coefficient and $p$ values were computed pairwise in MATLAB using the "corr" command. Estuary means are reported as the mean \pm one standard deviation.

Given the skewness of variables in this multivariate data set, discriminant analysis was carried out using nonparametric permutation multivariate analysis for variances (NPMANOVA; Anderson 2001) to determine statistical significance, combined with an ordination test, canonical analysis of principle coordinates (CAP; Anderson and Willis, 2003), to determine relatedness between these variables. NPMANOVA is used for hypothesis testing for differences among categories within a multivariate set of response variables. The 
Table 1

Seasonal Means of Physical Parameters in Apalachicola Bay and Barataria Bay

\begin{tabular}{lccc}
\hline Location and time & Discharge $\left(\mathrm{m}^{3} / \mathrm{s}\right)$ & Salinity & Water temperature $\left({ }^{\circ} \mathrm{C}\right)$ \\
\hline Apalachicola Bay & AP River & & \\
March 2015 (spring) & $807 \pm 21$ & $16.1 \pm 11.9$ & $24.3 \pm 0.8$ \\
November 2015 (fall) & $254 \pm 18$ & $22.3 \pm 8.7$ & $27.1 \pm 0.6$ \\
July 2016 (summer) & $315 \pm 20$ & $19.8 \pm 8.4$ & $31.3 \pm 0.8$ \\
Barataria Bay & DPFW & & \\
July 2015 (summer) & $30 \pm 3$ & $20.5 \pm 4.7$ & $29.4 \pm 1.4$ \\
March 2016 (spring) & $39 \pm 3$ & $13.4 \pm 3.0$ & $22.6 \pm 0.4$ \\
October 2016 (fall) & - & $16.3 \pm 3.3$ & $27.3 \pm 0.5$ \\
\hline
\end{tabular}

Note. For Apalachicola Bay, data were collected 6-12 days prior to sampling at Apalachicola River near Sumatra, FL. For Barataria Bay, data were collected 25-30 days prior to sampling at Davis Pond Freshwater Diversion (DPFW), LA. In addition to DPFW, other major sources of freshwater to Barataria Bay include Barataria Bay Waterway, Bayou des Allemands, Lake Cataouatche, Wilkinson Bayou, Bay Batiste, and Lake Brande Ecaille. Days prior were selected based on residence times of each bay. All values are given as mean \pm standard deviation.

CAP analysis is a form of constrained ordination where there are both response and grouping variables, in contrast to principal components analysis which only has responses. CAP is a way to visualize and verify the NPMANOVA analysis and test the variability among groups. Additionally, the model can be validated using the leave one out cross-validation method. NPMANOVA and CAP were conducted using the fathom toolbox for MATLAB (Jones, 2012). The following parameters were included in CAP analysis: salinity, DOC, $\delta^{13}$ C-DOC, POC, TSS, pC:N, $\delta^{13} \mathrm{C}-\mathrm{POC}, \mathrm{d} \Sigma_{8}, \mathrm{~d} \Lambda_{8} \mathrm{~d}(\mathrm{Ad}: \mathrm{Al})_{\mathrm{P}}, \mathrm{d}(\mathrm{Ad}: \mathrm{Al})_{\mathrm{S}}, \mathrm{d}(\mathrm{Ad}: \mathrm{Al})_{\mathrm{V}}, \mathrm{dS}: \mathrm{V}, \mathrm{dC}: \mathrm{V}, \mathrm{p}$ $(\mathrm{Ad}: \mathrm{Al})_{\mathrm{P}}, \mathrm{pS}: \mathrm{V}, \mathrm{p} \Sigma_{8}$ (Table $\mathrm{S} 2$ : prefixes of "d" and "p" designate dissolved and particulate OM, respectively). Particulate lignin parameters were limited by the nondetectable concentration of $p$-coumaric acid and ferulic acid (Table S1) for AP summer.

\subsection{Flux Calculations}

Fluxes of DOC, POC, and dissolved and particulate lignin were calculated using the high-resolution Navy Coastal Ocean hydrodynamic model (NCOM) that covers the northeastern Gulf coast as previously described in Joshi et al. (Joshi et al., 2017, and references therein) and is briefly described here. The model was continuously run from 2015 to 2016 and was forced with tides and COAMPS meteorological data. The predicted ocean currents and sea level for 7 days around each sampling date for each bay were used to calculate fluxes. The open boundary conditions (sea level, temperature, salinity, and currents) were taken from the Navy's global HYCOM (Metzger et al., 2014). For each period, a constant concentration (but with spatial variation) derived with Objective Analysis from the in situ measurements of DOC, POC, and dissolved and particulate lignin was used to estimate their constituent fluxes by applying model volume fluxes computed from hourly currents and sea level at the openings of each bay. Volume fluxes out of the bays are positive values; fluxes into the bays are negative values. Mean and standard deviation of daily flux calculations computed for each of the three samplings in each bay multiplied by 365 to upscale daily to annual fluxes.

\section{Results}

\subsection{Hydrophysical Data}

The highest average river discharge $\left(807 \mathrm{~m}^{3} / \mathrm{s}\right)$ for the AR (Table 1), based on flow 6 to 12 days prior to each sampling period (March 2015, July 2015, and November 2016), occurred in March 2015. Average freshwater discharge from Davis Pond Freshwater Diversion at BB were based on flow 25-30 days prior to each sampling period (July 2015, March 2016, and October 2016), and the highest flow ( $\left.39 \mathrm{~m}^{3} / \mathrm{s}\right)$ occurred in March 2016 (Table 1). There was also a heavy local precipitation event in AP that occurred on 3 November 2015 (Joshi et al., 2017).

The range of salinity values for AP and BB were 0.1 to 35.3 and 5.4 to 28.3 , respectively. Mean salinity $(21.0 \pm 10.6)$ in AP was significantly higher than in $\mathrm{BB}(16.9 \pm 4.8 ; p<0.05)$. The seasonal variability of average salinity and water temperature for both bays are shown in Table 1. Apalachicola Bay estuary experienced high winds in March 2015 (spring), low winds in November 2015 (fall; except for November 2), and mixed 

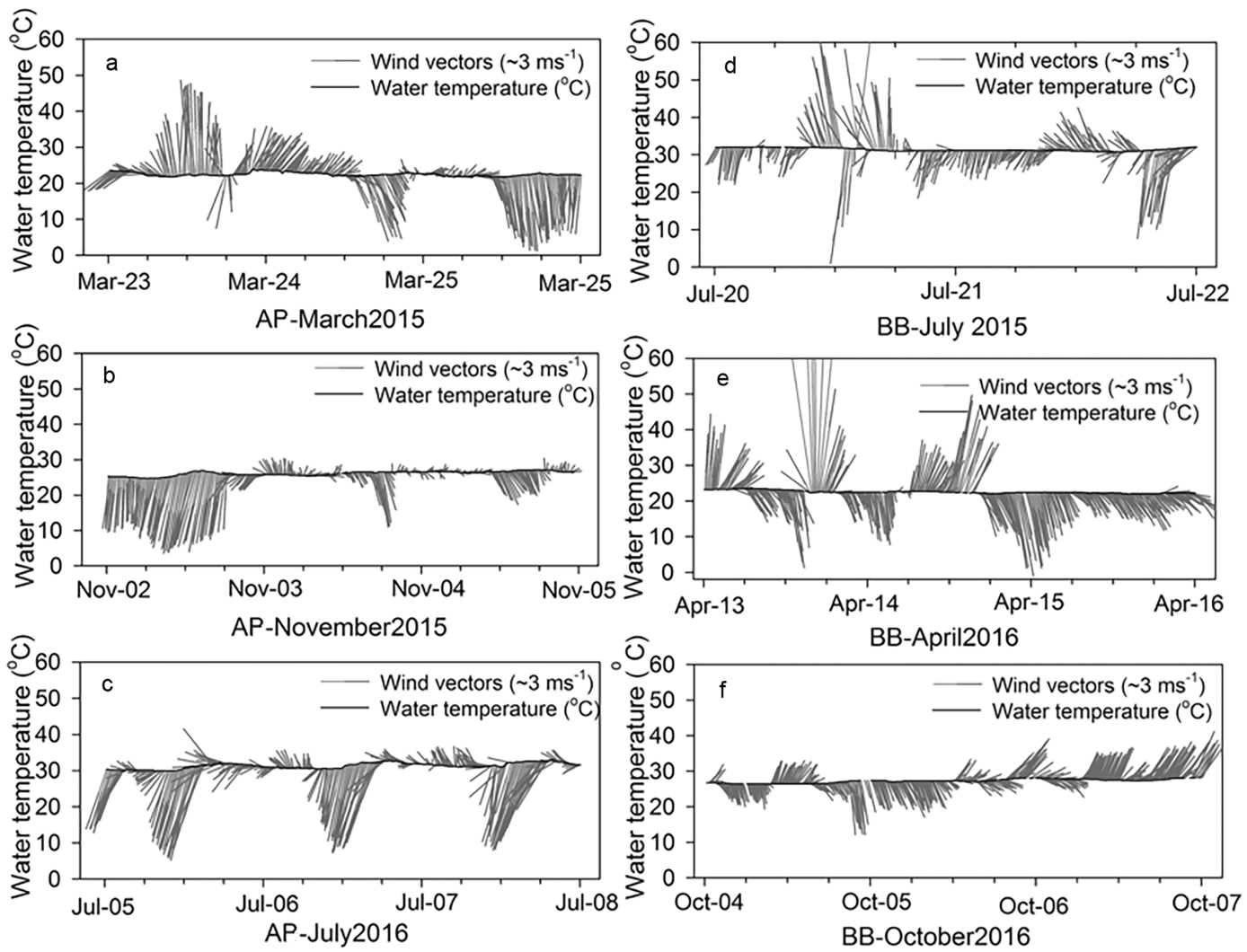

Figure 2. Time series of water temperature and wind vectors (wind speed and wind direction from true north) for Apalachicola (a-c) and Barataria (d-f) Bays. AP = Apalachicola Bay; BB = Barataria Bay.

diurnal winds in July 2016 (Figure 2). BB experienced occasional strong northerly winds in July 2015, strong winds (mostly northerly) in April 2015, and weak winds in October 2016 (Figure 2).

\subsection{Bulk Organic Carbon Concentrations}

\subsubsection{DOC}

The range of DOC concentrations for AP (without CR), CR, and BB were 101 to $738 \mu \mathrm{M}(\bar{x}=313 \pm 346$, $n=68), 176$ to $2,298 \mu \mathrm{M}(\bar{x}=1,115 \pm 707, n=14)$, and 205 to $888 \mu \mathrm{M}(\bar{x}=380 \pm 135, n=65)$, respectively. The mean DOC in the CR, entering AP, was significantly higher than the mean DOC of $\mathrm{BB}(p<0.05$; Figure 3). Apalachicola Bay (without CR) had a significantly $(p<0.05)$ negative correlation with salinity in November 2015 (fall) and in July 2016 (summer; Table S5), after heavy rainfall. BB had significantly $(p<0.05)$ negative correlation with salinity in all sampling periods (Table S5).

\subsubsection{POC, TSS, and Percent Carbon}

The range of POC concentrations for AP and BB were 15 to 236 and 77 to $633 \mu \mathrm{M}$, respectively. Mean POC $(72 \pm 43, n=80)$ in AP was significantly lower than in $\mathrm{BB}(237 \pm 107, n=77 ; p<0.05)$. The range for TSS concentrations for AP and BB were 0.3 to 135 and 26 to $165 \mathrm{mg} / \mathrm{L}$, respectively. Mean TSS (32.0 \pm 22.7 , $n=81)$ in AP was significantly higher than in $\mathrm{BB}(77.2 \pm 34.3, n=76 ; p<0.05)$. The range of percent carbon of $\mathrm{POC}$ for $\mathrm{AP}$ and $\mathrm{BB}$ were $0.4 \%$ to $23 \%$ and $1.3 \%$ to $8 \%$, respectively. Mean percent carbon for $\mathrm{AP}$ and $\mathrm{BB}$ were $(4 \pm 3 \%, n=81)$ and $(4 \pm 1 \%, n=76)$. The range of DOC:POC ratios for AP and BB were $0.9-57.0$ and $0.5-4.1$, respectively. Mean DOC:POC $(8.0 \pm 9.6)$ in AP was significantly higher than in BB $(1.8 \pm 0.8 ; p<0.05)$.

\subsection{Organic Carbon Composition}

\subsection{1. $\delta^{13} \mathrm{C}-\mathrm{DOC}, \delta^{13} \mathrm{C}-\mathrm{POC}$, and pC:N}

Apalachicola Bay had wider range of $\delta^{13} \mathrm{C}-\mathrm{DOC}(-30.2$ to $-18.2 \%, n=75)$ values than $\mathrm{BB}(-26.6 \%$ o to $-21.4 \%, n=76)$. Mean $\delta^{13} \mathrm{C}-\mathrm{DOC}(-24.8 \pm 0.9 \%)$ in $\mathrm{BB}$ was significantly more enriched than in AP 


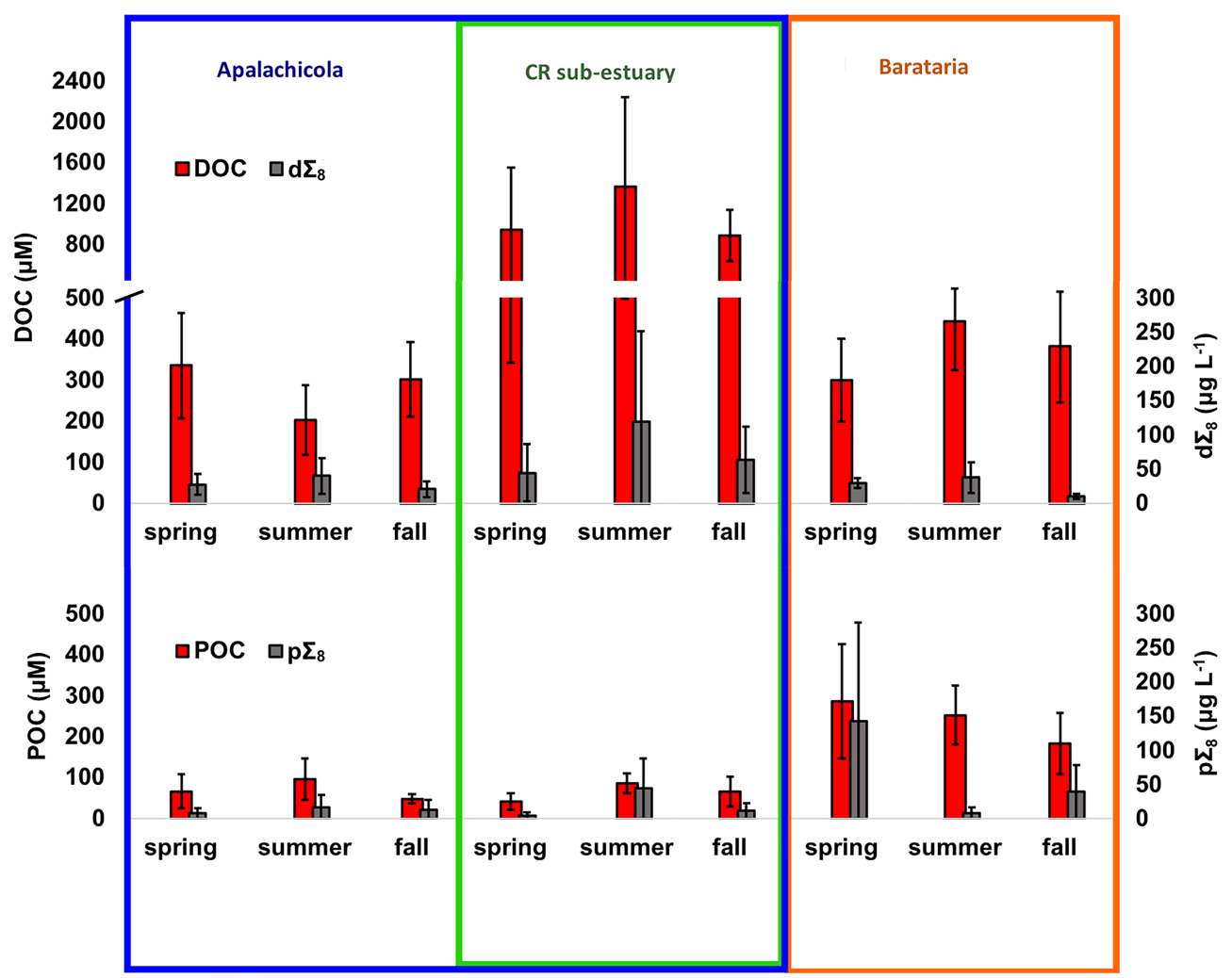

Figure 3. Seasonal means and standard deviations for POC, DOC, $\mathrm{d} \Sigma_{8}$, and $\mathrm{p} \Sigma_{8}$ concentrations at (a) Apalachicola Bay, (b) CR subestuary, and (c) Barataria Bay. POC = particulate organic carbon; DOC = dissolved organic carbon; $\mathrm{CR}=$ Carrabelle River

$(-26.3 \pm 2.7 \%$; $p<0.05)$. The range of $\delta^{13} \mathrm{C}$-POC values for AP and BB were $-34.3 \%$ to $-20.1 \%$ and $-29.3 \%$ o to $-21.2 \%$, respectively. Mean $\delta^{13} \mathrm{C}$-POC $(-24.0 \pm 1.3 \%, n=76)$ in BB was significantly more enriched than in $\mathrm{AP}(-26.8 \pm 2.4 \%, n=75 ; p<0.05)$. The average $\mathrm{pC}: \mathrm{N}$ values at AP were $\bar{x}=9.9 \pm 2.8$, while at BB the mean was $\bar{x}=8.8 \pm 1.9$. The range for $\mathrm{pC}: \mathrm{N}$ values for $\mathrm{AP}$ and $\mathrm{BB}$ were 5.1 to 18.1 and 6.4 to 13.4 , respectively. The highest $\mathrm{pC}: \mathrm{N}$ ratios $(\bar{x}=11.0 \pm 1.7)$ were observed in April during the strong northerly winds in BB (Figure 4).

Salinity was positively correlated with $\delta^{13} \mathrm{C}$ values for DOC and for POC in AP (Table S5), but in BB such relationships were not observed across all sampling trips. In fact, correlation with salinity was observed in two sampling trips: $\delta^{13} \mathrm{C}$-DOC was positively correlated in July 2015, and $\delta^{13} \mathrm{C}$-POC was positively correlated in April 2016 (Table S5).

\subsubsection{Dissolved and Particulate Lignin}

The range of $\mathrm{d} \Sigma_{8}$ concentrations for $\mathrm{AP}$ and BB were 1.6 to 318.4 and 5.7 to $62.4 \mu \mathrm{g} / \mathrm{L}$, respectively. Mean $\mathrm{d} \Sigma_{8}$ $(30.7 \pm 42.2 \mu \mathrm{g} / \mathrm{L})$ in AP was not significantly higher than in BB $(21.4 \pm 12.6 \mu \mathrm{g} / \mathrm{L} ; p>0.05)$. The highest concentrations of $\mathrm{d} \Sigma_{8}$ were observed in the CR transect (Figure 3b) and in the Bay proper (Figure 5). The range of concentrations of $\mathrm{d} \Lambda_{8}$ for $\mathrm{AP}$ and $\mathrm{BB}$ were 0.12 to 1.55 and 0.12 to $1.15 \mathrm{mg}$ per $100 \mathrm{mg}$ OC, respectively. Mean $\mathrm{d} \Lambda_{8}(0.48 \pm 0.28 \mathrm{mg}$ per $100 \mathrm{mg}$ OC, $n=75)$ in AP was not significantly higher than in BB $(0.49 \pm 0.28 \mathrm{mg}$ per $100 \mathrm{mg} \mathrm{OC}, n=76 ; p>0.05)$. The highest $\mathrm{d} \Lambda_{8}$ concentrations were observed in AP during the precipitation event in November 2015 at the bay proper and in BB during the high northerly winds in April 2016 (Figure 2b). Salinity was positively correlated with $\mathrm{d} \Sigma_{8}$ for all sampling sites in AP (Table S5), but in BB such relationships were not observed across all sampling trips (Table S5). Concentrations of LOPs and diagnostic ratios for all sites and sampling periods are listed in Table S4.

The range of $\mathrm{dC}: \mathrm{V}$ and $\mathrm{dS}: \mathrm{V}$ values for $\mathrm{AP}$ were 0.16 to 1.17 and 0.35 to 1.39 , respectively. At $\mathrm{BB}$, the range for $\mathrm{dC}: \mathrm{V}$, and $\mathrm{dS}: \mathrm{V}$ values were 0.34 to 2.05 and 0.87 to 1.83 , respectively (Figure $7 \mathrm{a})$. Mean dC:V (0.86 \pm 0.39 , 


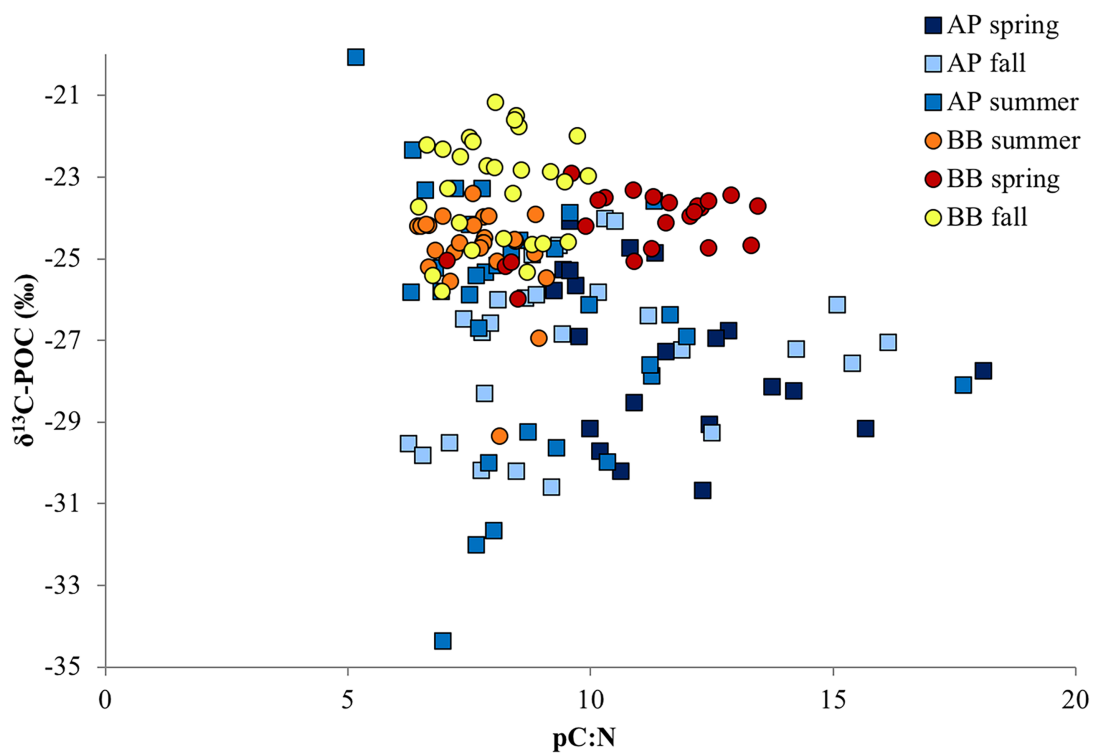

Figure 4. Seasonal $\delta^{13} \mathrm{C}$-POC values and $\mathrm{pC}: \mathrm{N}$ (molar) values at $\mathrm{AP}$ and $\mathrm{BB} . \delta^{13} \mathrm{C}$-POC is expressed in standard delta notation relative to Vienna Pee Dee Belemnite. $\delta^{13} \mathrm{C}-\mathrm{POC}=$ stable isotopic composition of particulate organic carbon; $\mathrm{AP}=$ Apalachicola Bay; $\mathrm{BB}=$ Barataria Bay.

$n=72)$ and $\mathrm{dS}: \mathrm{V}$ for $\mathrm{BB}(1.27 \pm 0.20, n=72)$ were significantly higher than those in $\mathrm{AP}(0.51 \pm 0.26, n=78$ and $0.82 \pm 0.20, n=78$, respectively $(p<0.05)$. Mean values for (Ad:Al)v at AP and BB were $1.16 \pm 0.40$ and $1.12 \pm 0.21$, respectively. The highest degradation ratios of $(\mathrm{Ad}: \mathrm{Al}) \mathrm{v}$ were observed in the $\mathrm{CR}$ transect $(\bar{x}=$ $1.63 \pm 0.30$; Table S4).

The range of $\mathrm{p} \Sigma_{8}$ concentrations for $\mathrm{AP}$ and $\mathrm{BB}$ were 0.32 to 91.9 and 5.0 to $513.7 \mu \mathrm{g} / \mathrm{L}$, respectively. Mean $\mathrm{p} \Sigma_{8}(73.2 \pm 108.0 \mu \mathrm{g} / \mathrm{L}, n=60)$ in BB was 9 times higher than in AP $(7.6 \pm 15.4 \mu \mathrm{g} / \mathrm{L}, n=60 ; p<0.05)$. In $\mathrm{BB}$, the highest concentrations of $\mathrm{p} \Sigma_{8}$ were observed during strong wind conditions in the spring (Figure $3 \mathrm{~b}$ ). The range of concentrations of $\mathrm{p} \Lambda_{8}$ for $\mathrm{AP}$ and $\mathrm{BB}$ were 0.05 to 16.58 and 0.24 to $9.44 \mathrm{mg}$ per $100 \mathrm{mg}$ OC, respectively. Mean $\mathrm{p} \Lambda_{8}$ in $\mathrm{BB}(2.9 \pm 2.7 \mathrm{mg}$ per $100 \mathrm{mg} \mathrm{OC}, n=60)$ was 2 times higher than
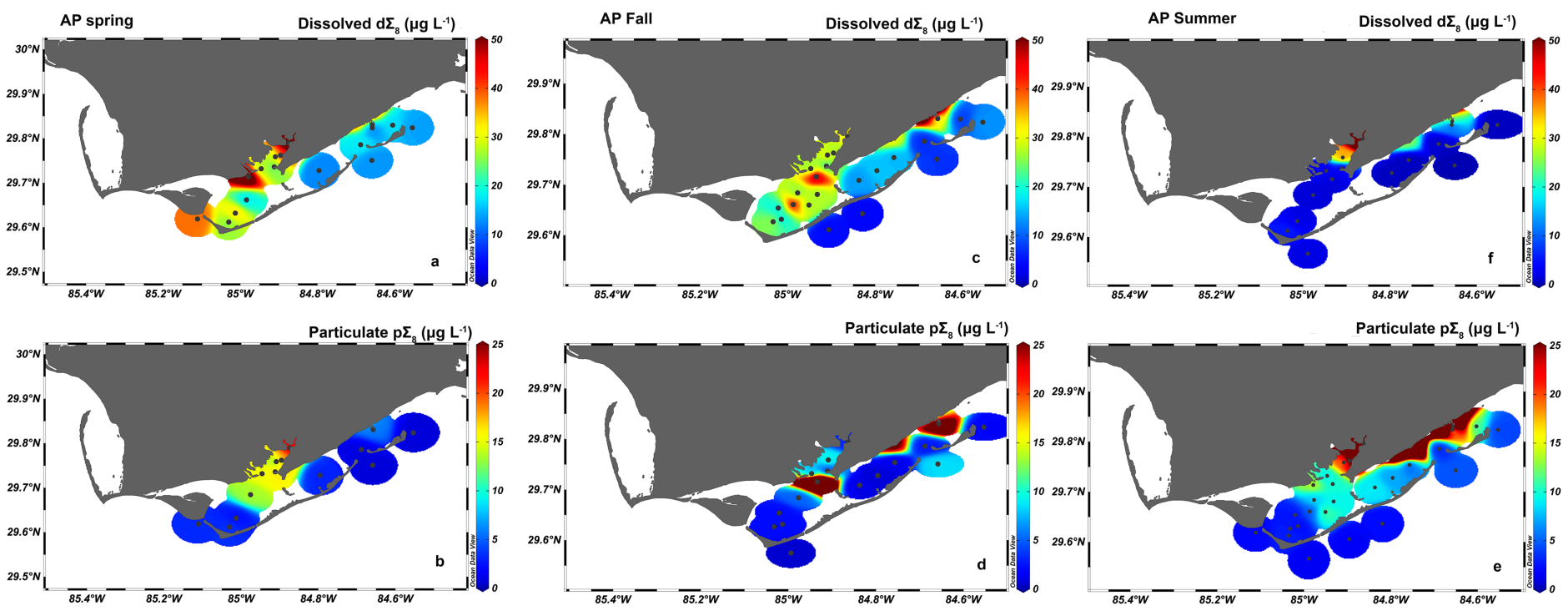

Figure 5. Seasonal distribution of dissolved $\left(\mathrm{d} \Sigma_{8} ; \mathrm{a}, \mathrm{c}, \mathrm{f}\right)$ and particulate $\left(\mathrm{p} \Sigma_{8} ; \mathrm{b}, \mathrm{d}, \mathrm{e}\right)$ lignin in Apalachicola Bay. AP = Apalachicola Bay 

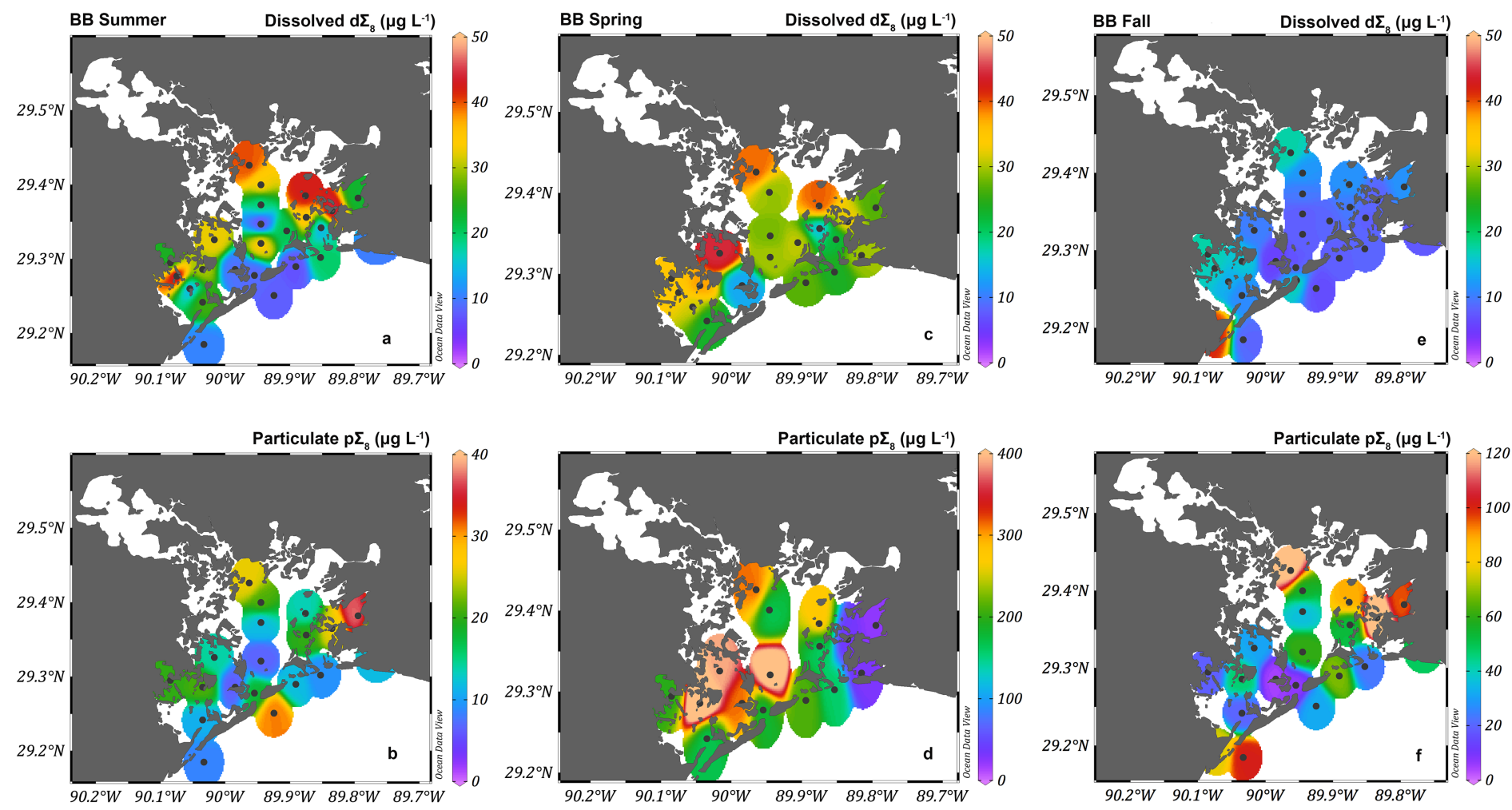

Figure 6. Seasonal distribution of dissolved $\left(\mathrm{d} \Sigma_{8} ; \mathrm{a}, \mathrm{c}, \mathrm{e}\right)$ and particulate $\left(\mathrm{p} \Sigma_{8} ; \mathrm{b}, \mathrm{d}, \mathrm{f}\right)$ lignin in Barataria Bay. BB $=$ Barataria Bay.

in $\mathrm{AP}(1.3 \pm 2.6 \mathrm{mg}$ per $100 \mathrm{mg} \mathrm{OC}, n=59 ; p<0.05)$. In $\mathrm{BB}$, the highest concentrations of $\mathrm{p} \Lambda_{8}$ were observed during strong wind conditions in the spring (Figures 2e and 6).

The range for $\mathrm{pC}: \mathrm{V}$ and $\mathrm{pS}: \mathrm{V}$ values for $\mathrm{AP}$ were 0.05 to 1.31 and 0.16 to 1.09 , respectively. At $\mathrm{BB}$, the range for $\mathrm{pC}: \mathrm{V}$ and $\mathrm{pS}: \mathrm{V}$ values were 0.15 to 0.86 and 0.27 to 1.43 , respectively (Figure $7 \mathrm{~b})$. Mean pC:V $(0.58 \pm 0.19$, $n=60)$ and $\mathrm{pS}: \mathrm{V}(1.08 \pm 0.28, n=60)$ for $\mathrm{BB}$ were significantly higher in $\mathrm{BB}$ than in $\mathrm{AP}(0.25 \pm 0.22, n=48$ and $0.59 \pm 0.21, n=54 ; p<0.05$; Table $\mathrm{S} 3$ and Figure $7 \mathrm{~b}$ ).

\subsection{CAP Analysis}

In the first CAP, NPMANOVA $F$ value was 13.0 with a $p$ value of $0.005(\mathrm{df}=95)$, indicating a significant difference between groups and appropriateness to proceed with CAP analysis. The allocation of sites into correct groups is $95.8 \%$, which is significantly different $(p<0.005)$ than that obtained by random allocation (17.5\%). Groups were separated by estuary along canonical axis I, which explained $24.6 \%$ of the variability (Figure 8b). BB had the following vectors with the same relative magnitude and direction: POC, TSS, $\delta^{13} \mathrm{C}-\mathrm{DOC}, \delta^{13} \mathrm{C}-\mathrm{POC}, \mathrm{dC}: \mathrm{V}, \mathrm{dS}: \mathrm{V}$, and $\mathrm{pS}: \mathrm{V}$. Vectors for TSS and POC had a large magnitude indicating that $\mathrm{BB}$ is a more particulate phase driven system than AP. In contrast, AP was separated by DOC, pC:N, p (Ad: $\mathrm{Al})_{\mathrm{P}}$, and $\mathrm{d}(\mathrm{Ad}: \mathrm{Al})_{\mathrm{V}}($ Figure 8$)$, indicating a more river-dominated system than BB. Seasonal variability was separated by canonical axis II, which explained $22.4 \%$ of the variability (Figure $8 \mathrm{~b}$ ); the separation along axis II appears related to extreme weather events, such as strong northerly winds on BB (spring) and high rainfall in AP (fall). The sampling period during strong northerly winds at BB was characterized by dP: $(\mathrm{S}+\mathrm{V}), \mathrm{p} \Lambda_{8}$, $\mathrm{p} \Sigma_{8}, \mathrm{dC}: \mathrm{V}$ and $\mathrm{pS}: \mathrm{V}$, indicating a nonwoody signature from either resuspended material or increased lateral flux from the marshes, while the end of the wet season at AP were characterized by $\mathrm{pC}: \mathrm{N}$ and $\mathrm{d} \Lambda_{8}$, indicating a terrestrial influence. AP had 70-100\% classification success, while BB had 100\% classification success from the cross-validation method (Table S6). AP summer was misclassified into AP spring (30\%), indicating overlap in criteria.

A second CAP analysis was carried out using only the lignin diagnostics ratios to test the difference between river- and marsh-derived lignin sources in the two bays. NPMANOVA $F$ value was 11.4 with a $p$ value of 0.005 

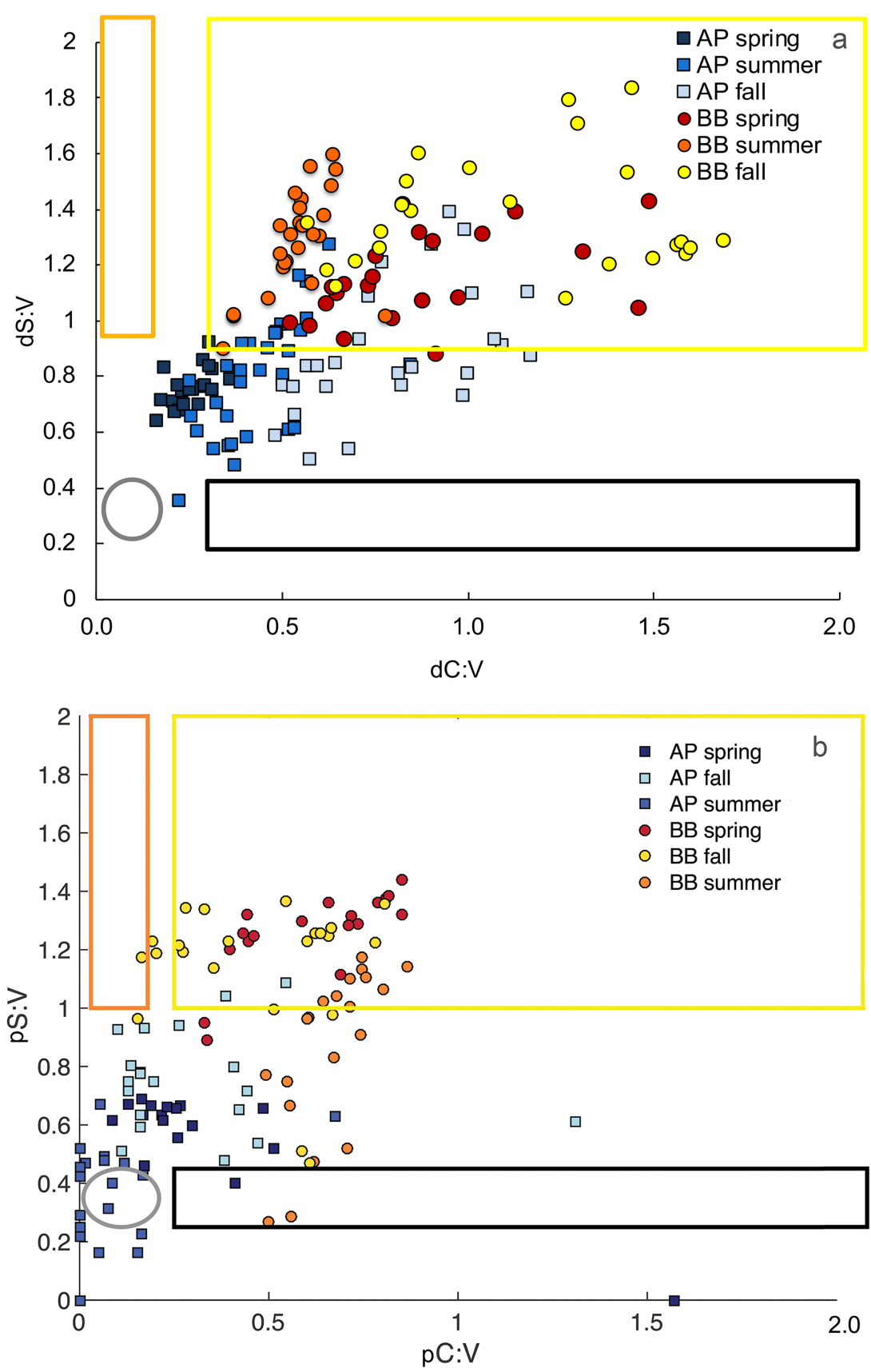

Figure 7. Plot of cinnamyl:vanillyl (C:V) versus syringyl:vanillyl (S:V) in dissolved lignin (a) and particulate lignin (b) Included are compositional ranges of major vascular plant tissues, such as gymnosperm woods (gray circle), gymnosperm needles (black rectangle), angiosperm wood (orange rectangle), and angiosperm leaf (yellow rectangle; Goñi et al., 1998; Hedges \& Mann, 1979). BB samples primarily fell in the range for angiosperm leaf and stem, while AP (including CR) samples primarily fell in the range for gymnosperm wood and needles. AP = Apalachicola Bay; $\mathrm{BB}=$ Barataria Bay; $\mathrm{CR}=$ Carrabelle River.

( $\mathrm{df}=97)$, indicating a significant difference between groups and appropriateness to proceed to with CAP analysis. The allocation of sites into correct groups is $87.8 \%$, which is significantly different $(p<0.005)$ than that obtained by random allocation (17.7\%). Canonical axis I explained $33.7 \%$ of the variability, while canonical axis II explained $27.1 \%$ of the variability (Figure 9a). Groups were separated along the diagonal of the canonical axes (Figure 9a), and BB sites were discriminated by dissolved and particulate C:V and S:V 

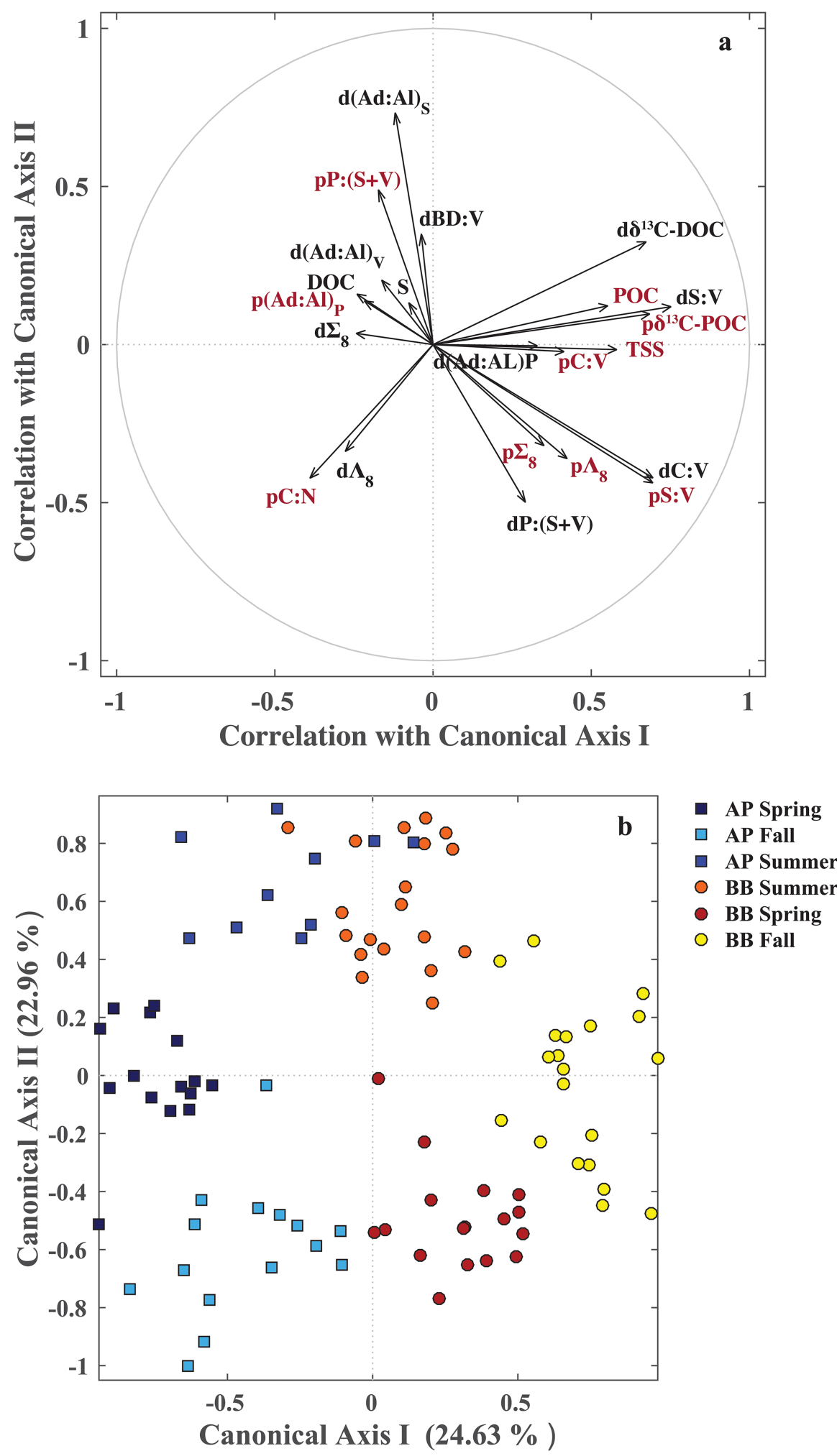

O BB Fall

Figure 8. (a) Canonical analysis of principle coordinates with canonical axes from AP and BB. Vectors indicate degree of correlation between organic carbon parameters. Red font represents particulate parameters, and black font represents dissolved parameters. (b) Sample distribution in the canonical space; spatial variability was separated along canonical axis I, while temporal variability was separated along canonical axis II. AP = Apalachicola Bay; $\mathrm{BB}=$ Barataria Bay; $\mathrm{DOC}=$ dissolved organic carbon; $\mathrm{POC}=$ particulate organic carbon; $\delta^{13} \mathrm{C}-\mathrm{DOC}=$ stable isotopic composition of DOC; $\delta^{13} \mathrm{C}-\mathrm{POC}=$ stable isotopic composition of POC. 

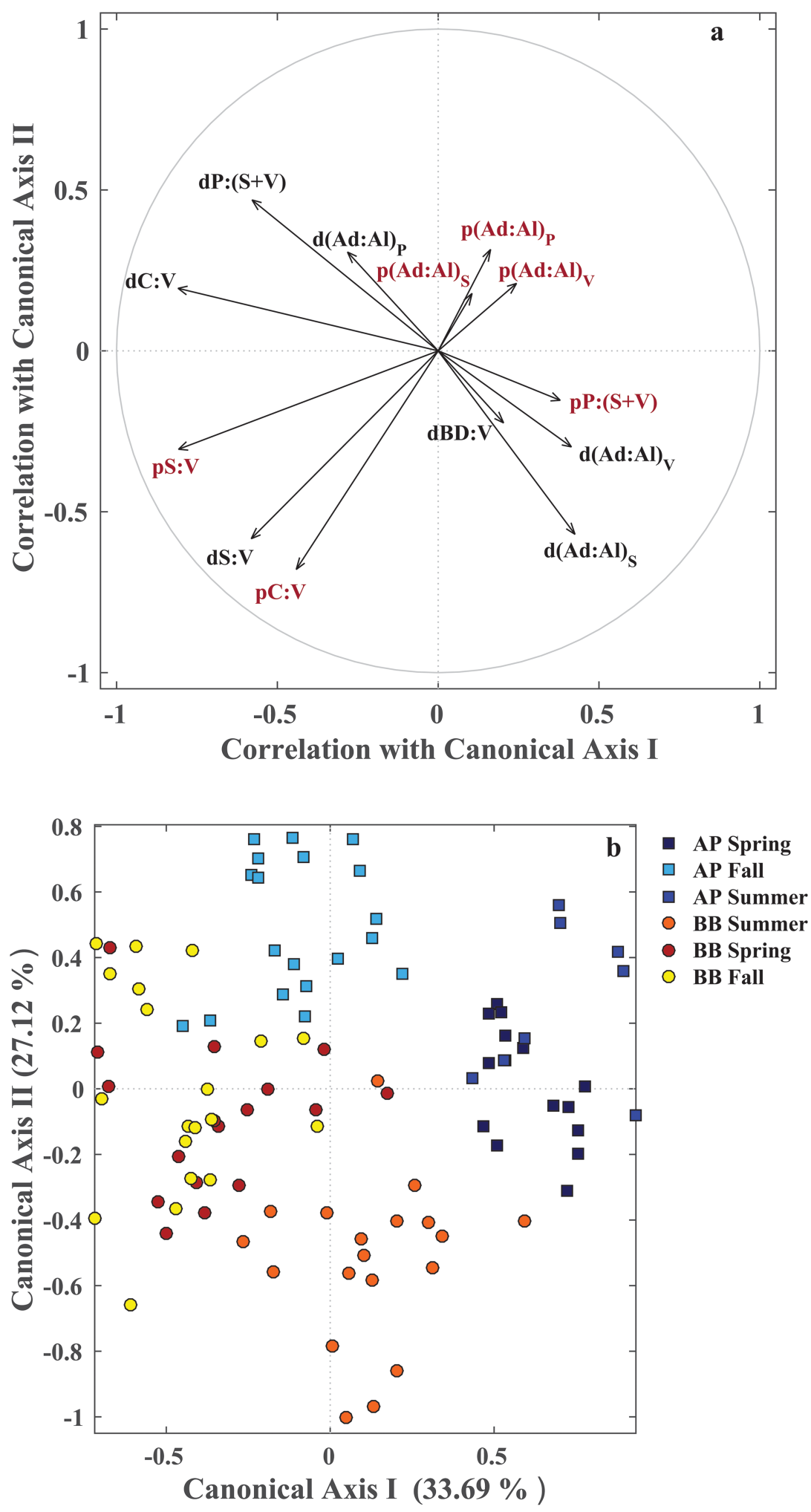

Figure 9. (a) Canonical analysis of principle coordinates with canonical axes from AP and BB. Vectors indicate degree of correlation between organic carbon parameters. Red font represents particulate parameters, and black font presents dissolved parameters. (b) Sample distribution in the canonical space; spatial variability was separated along canonical axis I, while temporal variability was separated along canonical axis II. AP = Apalachicola Bay; $\mathrm{BB}=$ Barataria Bay; $\mathrm{DOC}=$ dissolved organic carbon; $\mathrm{POC}=$ particulate organic carbon; $\delta^{13} \mathrm{C}-\mathrm{DOC}=$ stable isotopic composition of DOC; $\delta^{13} \mathrm{C}-\mathrm{POC}=$ stable isotopic composition of POC. 
Table 2

Fluxes for DOC, POC, and Dissolved and Particulate Lignin for Apalachicola and Barataria Bays

\begin{tabular}{|c|c|c|c|c|c|c|c|}
\hline & $\begin{array}{l}\text { Volume } \\
\mathrm{m}^{3} / \mathrm{s}\end{array}$ & $\begin{array}{l}\mathrm{DOC} \\
\mathrm{kg} / \mathrm{s}\end{array}$ & $\begin{array}{l}\mathrm{POC} \\
\mathrm{kg} / \mathrm{s}\end{array}$ & $\begin{array}{l}\mathrm{d} \Sigma_{8} \\
\mathrm{~kg} / \mathrm{s}\end{array}$ & $\begin{array}{c}\mathrm{d} \Lambda_{8} \\
\mathrm{~kg} \cdot(100 \mathrm{~kg} \mathrm{OC})^{-1} \cdot \mathrm{s}^{-1}\end{array}$ & $\begin{array}{l}\mathrm{p} \Sigma_{8} \\
\mathrm{~kg} / \mathrm{s}\end{array}$ & $\begin{array}{c}\mathrm{p} \Lambda_{8} \\
\mathrm{~kg} \cdot(100 \mathrm{~kg} \mathrm{OC})^{-1} \cdot \mathrm{s}^{-1}\end{array}$ \\
\hline \multicolumn{8}{|c|}{ Apalachicola Bay } \\
\hline Spring & 757 & 2.05 & 0.47 & $1.85 \times 10^{-2}$ & $4.60 \times 10^{-4}$ & $3.18 \times 10^{-3}$ & $4.50 \times 10^{-4}$ \\
\hline Fall & 272 & 0.65 & 0.25 & $9.93 \times 10^{-3}$ & $2.60 \times 10^{-4}$ & $1.23 \times 10^{-3}$ & $2.10 \times 10^{-4}$ \\
\hline Summer & 441 & 1.13 & 0.36 & $4.71 \times 10^{-3}$ & $1.60 \times 10^{-4}$ & $2.57 \times 10^{-3}$ & $1.10 \times 10^{-4}$ \\
\hline Mean & 490 & 1.28 & 0.36 & $1.10 \times 10^{-2}$ & $2.93 \times 10^{-4}$ & $2.33 \times 10^{-3}$ & $2.57 \times 10^{-4}$ \\
\hline $\mathrm{SD}$ & 246 & 0.71 & 0.11 & $6.96 \times 10^{-3}$ & $1.53 \times 10^{-4}$ & $9.98 \times 10^{-4}$ & $1.75 \times 10^{-4}$ \\
\hline \multicolumn{8}{|c|}{ Barataria Bay } \\
\hline Summer & 410 & 1.34 & 0.83 & $5.39 \times 10^{-3}$ & $1.50 \times 10^{-4}$ & $6.92 \times 10^{-3}$ & $4.20 \times 10^{-4}$ \\
\hline Spring & 126 & 0.44 & 0.50 & $1.77 \times 10^{-3}$ & $6.00 \times 10^{-5}$ & $2.54 \times 10^{-2}$ & $7.30 \times 10^{-4}$ \\
\hline Fall & 225 & 0.75 & 0.87 & $2.02 \times 10^{-3}$ & $6.00 \times 10^{-5}$ & $1.30 \times 10^{-2}$ & $3.10 \times 10^{-4}$ \\
\hline Mean & 254 & 0.84 & 0.73 & $3.06 \times 10^{-3}$ & $9.00 \times 10^{-5}$ & $1.51 \times 10^{-2}$ & $4.87 \times 10^{-4}$ \\
\hline SD & 144 & 0.46 & 0.20 & $2.02 \times 10^{-3}$ & $5.20 \times 10^{-5}$ & $9.42 \times 10^{-3}$ & $2.18 \times 10^{-4}$ \\
\hline
\end{tabular}

Note. Volume flux is also shown. $\mathrm{SD}=$ standard deviation; $\mathrm{DOC}=$ dissolved organic carbon; $\mathrm{POC}=$ particulate organic carbon.

(Figure 9b). The AP sites were characterized by the following particulate lignin source parameters: $\mathrm{p}$ (Ad:Al) $\mathrm{v}, \mathrm{p}(\mathrm{Ad}: \mathrm{Al})_{\mathrm{S}}, \mathrm{p}(\mathrm{Ad}: \mathrm{Al})_{\mathrm{P}}, \mathrm{pP}:(\mathrm{S}+\mathrm{V})$, and $\mathrm{d}(\mathrm{Ad}: \mathrm{Al})_{\mathrm{V}}($ Figure $9 \mathrm{~b})$. Additionally, fall sampling periods for both

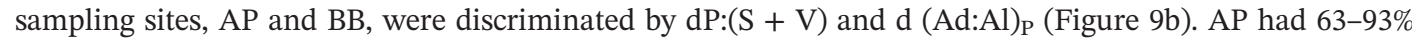
classification success, while BB had $82-95 \%$ classification success from the cross-validation method (Table S7). AP summer was misclassified into AP spring (25\%), indicating overlap in criteria.

\subsection{Volume Fluxes of $\mathrm{OC}$ and Lignin}

In the river-dominated AP, water volume flux out of the bay is very similar to the AR discharge (Table 2). However, in $\mathrm{BB}$, in addition to the water discharge at DPFW, the bay receives major inputs from other sources such as BB Waterway, Bayou des Allemands, and Lake Cataouatche, resulting in larger uncertainty in the volume flux than AP. In general, fluxes of DOC from AP were higher than those from BB (Table 2). In $\mathrm{AP}$, mean fluxes of DOC $(1.28 \pm 0.71 \mathrm{~kg} / \mathrm{s})$ were about fourfold greater than POC $(0.36 \pm 0.11 \mathrm{~kg} / \mathrm{s})$. By contrast, in BB, mean fluxes of DOC $(0.84 \pm 0.46 \mathrm{~kg} / \mathrm{s})$ were only about $15 \%$ higher than POC $(0.73 \pm 0.20 \mathrm{~kg} / \mathrm{s})$. Fluxes of DOC and POC from each bay were highest when volume fluxes were highest (Table 2). Lignin fluxes generally followed the same patterns. Mean dissolved lignin flux $\left(1.10 \pm 0.07 \times 10^{-2} \mathrm{~kg} / \mathrm{s}\right)$ in AP was higher than mean particulate lignin flux $\left(2.33 \pm 1.00 \times 10^{-3} \mathrm{~kg} / \mathrm{s}\right)$ by nearly a factor of 5 . However, particulate lignin flux $\left(1.51 \pm 0.94 \times 10^{-2} \mathrm{~kg} / \mathrm{s}\right)$ was fivefold greater than dissolved lignin flux $(3.06 \pm 2.02 \times 10$ ${ }^{-3} \mathrm{~kg} / \mathrm{s}$ ) in BB.

The difference between dominant forms of lignin flux was evident in the carbon-normalized yield flux (Table 2). In AP, both mean $\mathrm{d} \Lambda_{8}$ and $\mathrm{p} \Lambda_{8}$ flux values were of similar magnitude $\left(2.93 \pm 1.53 \times 10^{-4}\right.$ and $2.57 \pm 1.57 \times 10^{-4} \mathrm{~kg}$ per $100 \mathrm{~kg} \mathrm{OC}$, respectively). However, in BB, mean p $\Lambda_{8}$ flux $\left(4.87 \pm 2.18 \times 10^{-4} \mathrm{~kg}\right.$ per $100 \mathrm{~kg} \mathrm{OC})$ was far larger than mean $\mathrm{d} \Lambda_{8}$ flux $\left(9.00 \pm 5.20 \times 10^{-5} \mathrm{~kg}\right.$ per $\left.100 \mathrm{~kg} \mathrm{OC}\right)$.

\section{Discussion}

\subsection{Mobilization and Sources of POC and DOC to Surface Waters}

\subsubsection{Barataria DOC}

Flooding of marshes fringing BB occurs in a region of the GoM experiencing some of the highest RSL rise rates in North America. Although DOC concentrations in BB did not differ significantly between seasons, higher concentrations of $\Lambda_{8}$ (reflecting nonmarine DOC), POC, and TSS occurred during the period of strong northerly winds (April), indicating mobilization from erosion of marsh sediments and higher resuspension of bottom sediments in the bay. DOC concentrations in BB was within the range found in previous studies (Happ et al., 1977; Liu et al., 2019), despite the extensive net wetland loss since this work was published 40 years ago. For example, an estimated $3.5 \times 10^{9} \mathrm{~m}^{2}$ wetlands has been lost from Louisiana coastal wetlands over the period of 1956 to 2006 (Barras et al., 2008; Turner, 2011). The higher release of DOC from BB 
marshes compared to Fourleague Bay, a geologically younger region of the Mississippi/Atchafalaya delta complex, has been attributed to deteriorating (submerging) stage of deltaic marsh succession (Childers \& Day, 1990). Export of DOC from marshes to BB is highest shortly after flooding during flood tide (Childers \& Day, 1990). Even in nondeteriorating phases of marsh succession, many marshes have been shown to be important sources of DOC (Bianchi et al., 2009; Moran \& Hodson, 1990; Tzortziou et al., 2008). The lack of increase in the average DOC concentration, relative to the Happ et al. (1977) values, could be due to the relatively short residence time of water in the bay prior to its export to the shelf, compared to the much longer time frame at which these marshes have been eroding. Additionally, the decrease of DOC from in BB has been related to massive deposition of inorganic sediments related to Hurricanes Katrina and Rita in 2005 (Liu et al., 2019; Turner et al., 2006).

Despite the lack of increase in DOC in BB during a period of extensive wetland loss, DOM geochemical proxies clearly showed evidence of marsh-derived sources. C4 plants such as Spartina spp. exhibit enriched $\delta^{13} \mathrm{C}$ values in their tissues $(-15 \%$ o to $-10 \%$ ) owing to a different mode of carbon fixation than $\mathrm{C} 3$ plants which have much more depleted values (approximately $-29 \%$ o to $-27 \%$; Fogel \& Cifuentes, 1993). In Apalachicola Bay, Spartina had enriched $\delta^{13} \mathrm{C}$ values $-13 \pm 1 \%$ (Chanton and Lewis 1999). Further, grasses such as Spartina are enriched in cinnamyl phenols in nonwoody tissue; these angiosperms also have elevated syringyl phenols indicative of marsh inputs (Bianchi et al., 2007). Elevated ratios of C:V and S:V indicating strong grass contributions to DOC in Barataria Bay were therefore consistent with sources originating from Spartina and other dominant angiosperm vegetation in the fringing marshes of Barataria Bay (Beland et al., 2016). However, black mangrove (Avicennia germinans), a C3 plant, encroachment into the region also is prevalent (Henry \& Twilley, 2013). A mixture of 75\% terrestrial (-28\%o) and $25 \%$ marsh-derived $(-15 \%$; depleted to account for mangrove and other $\mathrm{C} 3$ plant contribution) sources would produce the mean $\delta^{13} \mathrm{C}$ DOC value we measured for BB, $-24.8 \%$. Therefore, the character of DOC in BB clearly reflects influence of marsh sources in this region of high RSL rise.

\subsubsection{Barataria POC}

Flooding of marshes fringing BB also had substantial impact on POC dynamics. Wave-induced subaqueous platform release of POC due to retreat of marsh shoreline has been shown to have POC yields of $37 \times 10^{6} \mathrm{~kg} /$ year (Wilson \& Allison, 2008) and $15.7 \times 10^{6} \mathrm{~kg} /$ year (Das et al., 2010). On the contrary, previous studies in tidal wetlands have suggested an import of chlorophyll and other POC by deposition onto the marsh platform at ebbing tide (Osburn et al., 2015; Tzortziou et al., 2011). POC dynamics in BB revealed a seasonal difference in the relative influence of wetland versus primary production as key sources of $\mathrm{C}$ exported from the bay.

The relatively enriched $\delta^{13} \mathrm{C}$-DOC and $\delta^{13} \mathrm{C}$-POC values in $\mathrm{BB}$ compared to AP are explained by a mixture of terrigenous and wetland-derived material, the latter being influenced by Spartina. For both DOC and POC, BB lignin data fell squarely into nonwoody angiosperm tissue that characterizes grasses such as Spartina (Figures 7a and 7b). Using a simple two-end-member mixing model as was done for DOC, a 70:30 mixture river and marsh end-members would produce the mean $\delta^{13} \mathrm{C}$-POC values of $-24.1 \%$ measured for $\mathrm{BB}$. In fact, this assessment is consistent with the nearly twofold higher $\mathrm{p} \Lambda_{8}$ values we measured for POC relative to DOC $\left(\mathrm{d} \Lambda_{8}\right)$ in BB (Figures 10b and 10d). Thus, our evidence showed that both DOC and POC in BB carry a strong marsh signal from Spartina.

While marsh-derived sources of POC were dominant during spring and summer in BB (Figure 8b), in fall, when winds were relatively weaker than spring, lower TSS, lower pC:N, and enriched $\delta^{13} \mathrm{C}-\mathrm{POC}$ (Table S8) values were more indicative of algal-derived production. This supports previous work that BB marshes are exporting marsh-derived OM to the inner Louisiana shelf (Bianchi et al., 2011). Previous work has also suggested that much of the POC is derived from phytoplankton in the lower bay (Wissel et al., 2005). In fact, because of its close proximity to MR plume waters, it has been estimated that BB imports nitrate $\left(7 \times 10^{6} \mathrm{~kg} \mathrm{~N}-\mathrm{NO}_{3} /\right.$ year) from the coastal plume waters, which supports BB phytoplankton (Das et al., 2010).

\subsubsection{Apalachicola DOC}

The highest dissolved $\Lambda_{8}$ values and depleted $\delta^{13} \mathrm{C}$-DOC were observed throughout AP during spring and fall, reflective of terrestrially derived DOC, when river flow and winds were higher than in the wet season sampling (summer; Table 1 and S7). This was likely attributed to stronger surface currents at this timewhich can be linked with greater net water transport toward the shelf (Joshi, D'Sa, et al., 2017). Despite 

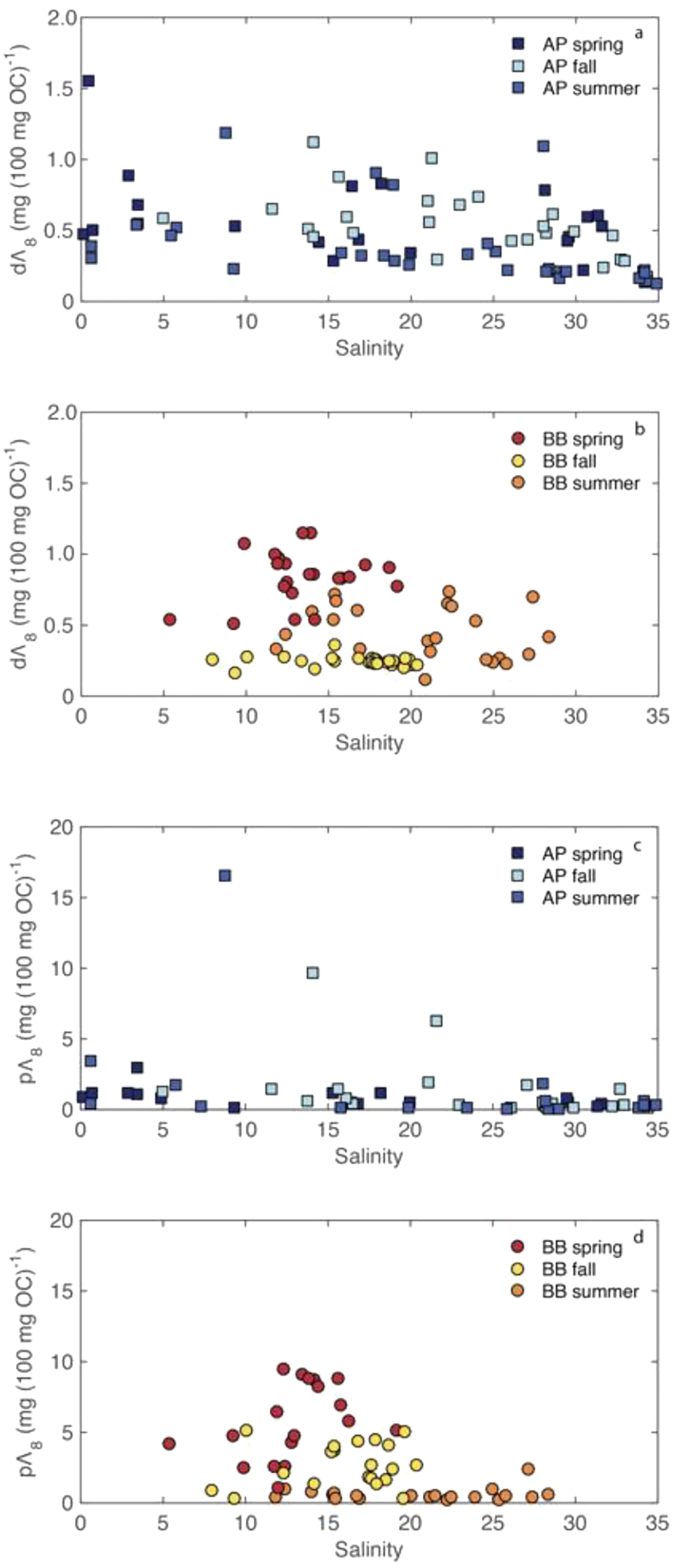

Figure 10. Seasonal relationships between salinity and $d \Lambda_{8}$ and $p \Lambda_{8}$ concentrations at $A P(a$ and $c)$ and $B B(b$ and $d)$. $\mathrm{AP}=$ Apalachicola Bay; $\mathrm{BB}=$ Barataria Bay .

the reduced $\mathrm{AR}$ and $\mathrm{CR}$ flows, and weak winds during the fall compared to spring, there were no significant differences in mean DOC concentrations in AP, with DOC exhibiting conservative behavior with salinity in both months. A high rainfall event and associated run-off was reported in AP during 
the fall (Joshi, D'Sa, et al., 2017), which resulted in high chromophoric DOM and DOC values observed near the AR and CR, which stayed confined to these river plumes. The highest dissolved $\Lambda_{8}$ values in AP were also associated with these riverine plumes. Lower $\mathrm{C}: \mathrm{V}$ ratios of dissolved lignin in the upper reaches of AP further supported a greater importance of fluvial inputs of woody-derived materials as opposed to marsh-derived materials, as observed for BB (Table 1). Similar to that found for chromophoric DOM (Joshi, D'Sa, et al., 2017), stronger winds and tides are needed to further distribute this riverine-derived DOM throughout AP. In particular, persistent cold-northerly winds coupled with ebb-tidal periods can transport low-salinity water to more southern reaches of the bay (Liu \& Huang, 2009). In March, when fluvial inputs were higher, we observed the depleted $\delta^{13} \mathrm{C}$-DOC throughout AP, likely indicative of a soil source. Using a combination of satellite-, field-, and model-based observations, Joshi et al. (Joshi, D'Sa, et al., 2017) showed that DOC stocks in AP were also higher during spring $\left(\sim 3.71 \times 10^{6} \mathrm{~kg} \mathrm{C}\right)$ than during fall $\left(\sim 4.07 \times 10^{6} \mathrm{~kg} \mathrm{C}\right)$.

\subsubsection{Apalachicola POC}

Higher TSS and more depleted $\delta^{13} \mathrm{C}$-POC near the northern reaches of AP reflect inputs of terrestrially derived $\mathrm{C}$ associated with riverine sources (Table S9). Using a stable isotopic mixing model, previous work in AP has shown the greatest fractions of terrestrially derived OM (e.g., 40\% to 58\%) in sediments near the river mouths (Chanton \& Lewis, 2002). Nevertheless, earlier work has shown that litter from forest vegetation in the watersheds of $\mathrm{AR}$ and $\mathrm{CR}$ amounts to $3.6 \times 10^{5}$ metric tons of organic material to the collective floodplain (Elder \& Cairns, 1982), with more than $50 \%$ of it being transported to the AP during spring flooding events (Mattraw \& Elder, 1984). In addition to the inputs of POC from bottomland hardwood and tupelo-cypress forests, there were likely POC inputs from freshwater emergent aquatic vegetation, both $\mathrm{C}_{3}$ (e.g., sawgrass [Cladium spp.], bulrush [Scirpus spp.], cattail [Typha spp.], and black needlerush [Juncus roemerianus]) and $\mathrm{C}_{4}$ (e.g., Spartina spp.), as well as submergent aquatic vegetation (e.g., Vallisneria americana and Ruppia maritima)—commonly found around in the freshwater/brackish waters of AR and CR river mouths (Livingston, 1984). For example, the high-precipitation event during fall had the highest concentration of $\mathrm{C}: \mathrm{V}$ and $\mathrm{S}: \mathrm{V}$ in indicating both emergent aquatic vegetation and submergent aquatic vegetation sources. Despite these systems being largely dominated by blackwater DOC inputs, fluvial inputs of POC from allochthonous (point and nonpoint sources) and autochthonous sources, with minimal inputs of mineralogic material, are important at certain times of the year in the northern reaches of AP.

\subsection{Comparisons Between Divergent Estuarine Systems Through CAP Analysis}

In the first CAP analysis, canonical axis I separated the fundamental differences between the two bays with respect to DOM and POM properties. BB was clearly particle-dominated, while AP was river dominated; the dominance was expressed in the properties of both DOM and POM. Canonical axis II showed the variability DOM and POM properties due to seasons but also highlights effects of the high-wind and high-precipitation events which occurred in BB and AP, respectively. During strong northerly winds in BB, CAP analysis indicated a nonwoody signature from either resuspended material or increased lateral flux from the marshes (Figure 8b). During a high-precipitation event at AP, there was a stronger terrestrial influence (Figure 8b). In AP, the dominant source of DOM and dissolved lignin phenols is likely from the AR and CR. In contrast, marsh sources are dominant in $\mathrm{BB}$ due to a lack of direct river inputs and high prevalence of living and submerged wetlands, both of which are subject to erosion under these high-energy conditions and hence contribute to enriched marsh export to coastal waters. These results for BB are consistent with enriched deposition of marsh-derived OM in surface sediments on the inner shelf of the GoM (Bianchi et al., 2011).

CAP analysis suggested that BB was distinguished by high $\mathrm{S}: \mathrm{V}$ and $\mathrm{C}: \mathrm{V}$ ratios both for DOC and POC (Figure 7). CAP analysis further showed that, when analyzed together, lignin, $\delta^{13} \mathrm{C}, \mathrm{C}: \mathrm{N}$, and TSS values displayed similar patterns (Figure 8). Combined, these geochemical data provide convincing evidence that coastal marsh inputs-either via direct erosional inputs or via resuspension of bay sediments that were once part of the marsh platform-contribute substantial amounts of the DOC and POC exported from BB to the GoM.

Indeed, a key result of the CAP analysis was the higher $\mathrm{C}: \mathrm{V}$ ratios in DOM and POM from BB compared that from AP (Figures 8 and 9). We examined OC-normalized cinnamyl phenols in DOM and POM between the two bays over seasons (Table S10). Median $\Lambda$ values for cinnamyls in BB DOM were higher than AP in spring, whereas AP values were higher in summer $(p<0.001$ in each Wilcoxon rank-sum test); no 
Table 3

Daily and Mean Annual Flux Estimates for DOC, POC, and Dissolved and Particulate Lignin

\begin{tabular}{lcccc}
\hline & DOC & POC & $\mathrm{d} \Sigma_{8}$ & $\mathrm{p} \Sigma_{8}$ \\
\hline Apalachicola Bay & & & & \\
$\quad$ Spring (kg/day) & $1.77 \times 10^{5}$ & $4.06 \times 10^{4}$ & $1.60 \times 10^{3}$ & $2.75 \times 10^{2}$ \\
$\quad$ Fall (kg/day) & $5.62 \times 10^{4}$ & $2.16 \times 10^{4}$ & $8.58 \times 10^{2}$ & $1.06 \times 10^{2}$ \\
$\quad$ Summer (kg/day) & $9.76 \times 10^{4}$ & $3.11 \times 10^{4}$ & $4.07 \times 10^{2}$ & $2.22 \times 10^{2}$ \\
Mean annual (kg C or kg & $4.03 \times 10^{7}$ & $1.14 \times 10^{7}$ & $3.48 \times 10^{5}$ & $7.34 \times 10^{4}$ \\
$\quad$ lignin/year) & & & & \\
SD & $2.24 \times 10^{7}$ & $3.47 \times 10^{6}$ & $2.20 \times 10^{5}$ & $3.15 \times 10^{4}$ \\
Barataria Bay & & & & \\
$\quad$ Summer (kg/day) & $1.16 \times 10^{5}$ & $7.17 \times 10^{4}$ & $4.66 \times 10^{2}$ & $5.98 \times 10^{2}$ \\
$\quad$ Spring (kg/day) & $3.80 \times 10^{4}$ & $4.32 \times 10^{4}$ & $1.53 \times 10^{2}$ & $2.19 \times 10^{3}$ \\
$\quad$ Fall (kg/day) & $6.48 \times 10^{4}$ & $7.52 \times 10^{4}$ & $1.75 \times 10^{2}$ & $1.12 \times 10^{3}$ \\
Mean annual (kg C or kg & $2.66 \times 10^{7}$ & $2.31 \times 10^{7}$ & $9.65 \times 10^{4}$ & $4.76 \times 10^{5}$ \\
$\quad$ lignin/year) & & & & \\
SD & $1.44 \times 10^{7}$ & $6.40 \times 10^{6}$ & $6.38 \times 10^{4}$ & $2.97 \times 10^{5}$ \\
\hline
\end{tabular}

Note. Mean and standard deviation (SD) are annual estimates made by upscaling; $\mathrm{DOC}=$ dissolved organic carbon; $\mathrm{POC}=$ particulate organic carbon. significant differences were found between these values in fall. Wilcoxon rank-sum test also revealed no significant difference between the bays when all three seasons were combined, though the median BB value (1.2 mg/100 mg OC) was higher than the median AP value $(0.88 \mathrm{mg} / 100 \mathrm{mg}$ OC). Spring and fall had periods of higher winds, which implies that open-water mixing of the water column releases proportionally more cinnamyls from $\mathrm{BB}$ than from AP compared to the more quiescent summer periods. Thus, a key mechanism for transport of marsh-derived wetland carbon into coastal waters may be inundation and erosion of OM stored in soils and sediments. In POM, carbon-normalized cinnamyls in BB were consistently and significantly higher than in AP (Table S10). We conclude that cinnamyl phenols, normalized to organic carbon, can serve as effective tracers of marsh-derived OM as shown previously (Bianchi et al., 2011).

\subsection{Carbon and Lignin Export to the Inner nGoM Shelf}

Lignin export was higher in BB than in AP (Table 3). Total annual lignin export (sum of mean dissolved and particulate) for AP was $4.22 \pm 2.35 \times 10^{5} \mathrm{~kg} /$ year compared to $5.73 \pm 2.50 \times 10^{5} \mathrm{~kg} /$ year for BB. Mean dissolved lignin export was lower in $\mathrm{BB}\left(9.65 \pm 6.38 \times 10^{4} \mathrm{~kg} /\right.$ year $)$ than in $\mathrm{AP}\left(3.48 \pm 2.20 \times 10^{5} \mathrm{~kg} /\right.$ year $)$, and mean particulate lignin export was higher in $\mathrm{BB}\left(4.76 \pm 2.97 \times 10^{5} \mathrm{~kg} / \mathrm{year}\right)$ than in $\mathrm{AP}\left(7.34 \pm 3.15 \times 10^{4} \mathrm{~kg} /\right.$ year; Table 3$)$. The reported dissolved lignin fluxes in this study are likely underestimates due to inefficiencies of Solid-Phase Extraction-Priority PolLutant (SPE-PPL) (41\% LOP recovery rates; Arellano et al., 2018). It was clear the largest fraction of export was particulate lignin from $\mathrm{BB}$, and indeed this fraction was larger even than the export of dissolved lignin from AP. This result was surprising given that the AR and CR drain coastal plain forested wetland areas and, as blackwater rivers, contain large amounts of lignin. We suggest that coastal marsh erosion is driving this comparatively large export of particulate lignin.

Erosion of coastal marshes is a major influence on the export of DOM and POM to the GoM from its bays. Previous work has suggested that POM and DOM derived from coastal marshes is exported to the inner shelf of Louisiana (Bianchi et al., 2009; Sampere et al., 2008). Assuming a carbon content in wetland soils of $0.026 \mathrm{~g} / \mathrm{cm}^{3}$ (Gosselink \& Pendleton, 1984), recent work has estimated an annual total OC export of $109 \times 10^{6} \mathrm{~kg}$ from BB to the Louisiana shelf (Das et al., 2010). Different estimates for POC export from BB were within the same order of magnitude from work by Wilson and Allison $\left(2008 ; 37 \times 10^{6} \mathrm{~kg} / \mathrm{year}\right)$ and Das et al. (2010; $15.7 \times 10^{6} \mathrm{~kg} /$ year). In fact, Wilson and Allison (2008) suggested that as much as approximately $40 \%$ of POC, derived from marsh erosion, is likely exported to the coastal GoM. Our results for annual POC export were $11.4 \times 10^{6} \mathrm{~kg}$ for AP and $23.1 \times 10^{6} \mathrm{~kg}$ from BB (Table 3). Lignin represented a greater fraction of $\mathrm{POC}$ in $\mathrm{BB}$ relative to $\mathrm{AP}$ and exhibited $\mathrm{C}: \mathrm{V}$ ratios indicative of marsh plant sources (Table 2 and Figure 7). Our results are thus consistent with the interpretation that coastal marsh erosion is transferring comparatively large amounts of $\mathrm{OC}$ to the nGoM shelf.

Estimates of DOC fluxes out of AP were greater during spring $\left(1.63 \times 10^{5} \mathrm{~kg} \mathrm{C} /\right.$ day $)$ than during fall $\left(1.24 \times 10^{5} \mathrm{~kg} \mathrm{C} /\right.$ day), as a result of higher DOC stocks in fall, based on remote sensing algorithms used to predict DOC (Joshi, D'Sa, et al., 2017). Higher DOC fluxes to the shelf at this time were attributed to greater water volume fluxes and enhanced river discharge during the wet season. We obtained slightly different values for DOC fluxes during spring $\left(1.77 \times 10^{5} \mathrm{~kg} \mathrm{C} /\right.$ day $)$ and fall $\left(0.56 \times 10^{5} \mathrm{~kg} \mathrm{C} /\right.$ day $)$ using the observed DOC concentrations in NCOM (Table 3). Twilley (1985) estimated $48 \mathrm{~g} \mathrm{C/year} \mathrm{export} \mathrm{of} \mathrm{DOC} \mathrm{at} \mathrm{Rookery}$ Bay, FL, while D'Sa et al. (2018) estimated $0.25-0.86 \times 10^{6} \mathrm{~kg} \mathrm{C} /$ day of DOC flux days after Hurricane Harvey in Galveston Bay.

Upscaling fluxes to an annual scale (with acknowledgement to three flux estimates for each bay) provides some context for the magnitude of dissolved versus particulate lignin export annually (Table 3). Dissolved lignin export was $<1 \%$ of DOC for both bays yet nearly threefold greater for AP than BB. The blackwaterdominated rivers as well as coastal marshes in AP are the likely reason for this difference. By contrast, 
particulate lignin export was $<1 \%$ for AP but $>4 \%$ by BB, a startling difference that we attribute to coastal marsh erosion.

\section{Conclusions}

Rapid subsidence and wetland loss in the Mississippi Delta Plain has the potential to export large amounts of previously stored POM to the GoM. We used a multiproxy approach to determine the extent to which two types of nGoM estuaries, experiencing different rates of sea level rise, export dissolved and particulate OM derived from wetland, terrestrial, and marine sources. The marsh-derived content of POM and DOM collected from open waters was higher at BB than in the AP likely because the open-water nature of BB facilitates more wind-driven mixing and resuspension compared to AP and perhaps also due to higher rate of RSL rise in BB. Consequently, these processes drive mobilization of POC and DOC such that a major source of the marsh-derived $\mathrm{OM}$ is from sediments. Our results suggest that this mobilization of coastal marsh sources was dominant in BB in part due to lack of direct river inputs and by high prevalence of extant and submerged wetlands which exist under a system of active marsh erosion due to subsidence and sea level rise. Particulate lignin export was highest from BB and about fivefold greater than its dissolved lignin export. In $\mathrm{AP}$, marshes are better protected by extensive barrier islands, and thus the dominant source of DOM and dissolved lignin phenols is likely from upland vegetation carried downstream by the AR and CR as indicated by phenolic ratios. In this blackwater-river-dominated estuary, dissolved lignin export was about 5 times higher than particulate lignin export, in contrast to BB. These results have important implications of the net losses of wetland from the tidal marsh habitats in the nGoM, particularly since this area is highly vulnerable to RSL rise.

Recent work by Najjar et al. (2018) has shown the narrow slice of coastline occupied by tidal wetlands can be extremely important for coastal carbon cycling, but it is not clear what role wetlands play in exporting OM to the sea. Overall, our results suggest that coastal marsh erosion is driving a large export of carbon into coastal waters. This distinction, perhaps, clarifies the role of tidal inundation of coastal wetlands as mechanisms for mobilizing the carbon stored in them to adjacent waters.

Acknowledgments

This material is based upon work supported by NASA under Grant NNX14AO43G. Jessica Atar, Joanna Kinsey, and Derrick Vaughn are thanked for their assistance in sample collection and Jack Hutchings for his assistance in the sample analysis. Data and supporting information available online (https://doi.org/10.6084/m9. figshare.9702050).

\section{References}

Adame, M. F., \& Lovelock, C. E. (2011). Carbon and nutrient exchange of mangrove forests with the coastal ocean. Hydrobiologia, 663(1), 23-50.

Anderson, C. J., \& Lockaby, B. G. (2012). Seasonal patterns of river connectivity and saltwater intrusion in tidal freshwater forested wetlands. River Research and Applications, 28(7), 814-826.

Arellano, A. R., Bianchi, T. S., Hutchings, J. A., Shields, M. R., \& Cui, X. (2018). Differential effects of solid-phase extraction resins on the measurement of dissolved lignin-phenols and organic matter composition in natural waters. Limnology and Oceanography: Methods, 16(1), 22-34.

Barras, J., Beville, S., Britsch, D., Hartley, S., Hawes, S., Johnston, J., et al. (2003). Historical and projected coastal Louisiana land changes: 1978-2050. Louisiana, US: United States Geological Survey.

Barras, J. A., Bernier, J. C., \& Morton, R. A. (2008). Land area change in coastal Louisiana, a multidecadal perspective (from 1956 to 2006 ). Louisiana, US: US Department of the Interior, US Geological Survey.

Bauer, J., \& Bianchi, T. (2011). Dissolved organic carbon cycling and transformation. Treatise on estuarine and coastal science, 5, 7-67. https://doi.org/10.1016/B978-0-12-374711-2.00502-7

Beland, M., Roberts, D. A., Peterson, S. H., Biggs, T. W., Kokaly, R. F., Piazza, S., et al. (2016). Mapping changing distributions of dominant species in oil-contaminated salt marshes of Louisiana using imaging spectroscopy. Remote Sensing of Environment, 182, 192-207.

Bianchi, T. S., DiMarco, S. F., Smith, R. W., \& Schreiner, K. M. (2009). A gradient of dissolved organic carbon and lignin from TerrebonneTimbalier Bay estuary to the Louisiana shelf (USA). Marine Chemistry, 117(1-4), 32-41. https://doi.org/10.1016/j.marchem.2009.07.010

Bianchi, T. S., Filley, T., Dria, K., \& Hatcher, P. G. (2004). Temporal variability in sources of dissolved organic carbon in the lower Mississippi River. Geochimica et Cosmochimica Acta, 68(5), 959-967. https://doi.org/10.1016/j.gca.2003.07.011

Bianchi, T. S., Galler, J. J., \& Allison, M. A. (2007). Hydrodynamic sorting and transport of terrestrially derived organic carbon in sediments of the Mississippi and Atchafalaya Rivers. Estuarine, coastal and shelf science, 73(1-2), 211-222. https://doi.org/10.1016/j.ecss.2007.01.004

Bianchi, T. S., \& Morrison, E. (2018). Human activities create corridors of change in aquatic zones. Eos, 99. https://doi.org/10.1029/ 2018EO104743

Bianchi, T. S., Pennock, J. R., \& Twilley, R. R. (1999). Biogeochemistry of Gulf of Mexico estuaries. New York, NY: John Wiley \& Sons.

Bianchi, T. S., Wysocki, L. A., Schreiner, K. M., Filley, T. R., Corbett, D. R., \& Kolker, A. S. (2011). Sources of terrestrial organic carbon in the Mississippi plume region: Evidence for the importance of coastal marsh inputs. Aquatic Geochemistry, 17(4-5), 431-456.

Blum, M. D., \& Roberts, H. H. (2009). Drowning of the Mississippi Delta due to insufficient sediment supply and global sea-level rise. Nature Geoscience, 2(7), 488. https://doi.org/10.1038/NGEO553

Chanton, J., \& Lewis, F. G. (2002). Examination of coupling between primary and secondary production in a river-dominated estuary: Apalachicola Bay, Florida, USA. Limnology and Oceanography, 47(3), 683-697.

Chelsea Nagy, R., Graeme Lockaby, B., Kalin, L., \& Anderson, C. (2012). Effects of urbanization on stream hydrology and water quality: The Florida Gulf Coast. Hydrological Processes, 26(13), 2019-2030. 
Childers, D. L., \& Day, J. W. (1990). Marsh-water column interactions in two Louisiana estuaries. II. Nutrient dynamics, Estuaries, 13(4), 404-417.

Dame, R., \& Allen, D. (1996). Between estuaries and the sea, Journal of Experimental Marine Biology and Ecology, 200(1-2), 169-185. https:// doi.org/10.1016/S0022-0981(96)02642-1

Das, A., Justić, D., \& Swenson, E. (2010). Modeling estuarine-shelf exchanges in a deltaic estuary: Implications for coastal carbon budgets and hypoxia. Ecological Modelling, 221(7), 978-985. https://doi.org/10.1016/j.ecolmodel.2009.01.023

DeLaune, R., \& White, J. (2012). Will coastal wetlands continue to sequester carbon in response to an increase in global sea level?: a case study of the rapidly subsiding Mississippi river deltaic plain. Climatic Change, 110(1-2), 297-314. https://doi.org/10.1007/s10584-0110089-6

Dittmar, T., Hertkorn, N., Kattner, G., \& Lara, R. J. (2006). Mangroves, a major source of dissolved organic carbon to the oceans. Global biogeochemical cycles, 20(1).

D'Sa, E. J., Joshi, I., \& Liu, B. (2018). Galveston Bay and coastal ocean optical-geochemical response to Hurricane Harvey from VIIRS ocean color. Geophysical Research Letters, 45(19), 10,579-510,589.

Dulaiova, H., \& Burnett, W. C. (2008). Evaluation of the flushing rates of Apalachicola Bay, Florida via natural geochemical tracers. Marine Chemistry, 109(3-4), 395-408.

Elder, J. F., \& Cairns, D. J. (1982). Production and decomposition of forest litter fall on the Apalachicola River flood plain. Florida: Chapter B, Apalachicola River quality assessmentRep., USGPO.

Fogel, M. L., \& Cifuentes, L. A. (1993). Isotope fractionation during primary production, in Organic geochemistry, edited, pp. 73-98. Boston, MA: Springer.

Goñi, M. A., \& Hedges, J. I. (1995). Sources and reactivities of marine-derived organic matter in coastal sediments as determined by alkaline CuO oxidation. Geochimica et Cosmochimica Acta, 59(14), 2965-2981.

Goñi, M. A., Ruttenberg, K. C., \& Eglinton, T. I. (1998). A reassessment of the sources and importance of land-derived organic matter in surface sediments from the Gulf of Mexico. Geochimica et Cosmochimica Acta, 62(18), 3055-3075.

Gosselink, J., \& Pendleton, E. C. (1984). The ecology of delta marshes of coastal Louisiana: A community profile Rep. Louisiana, US: Louisiana State Univ Baton Rouge Center For Wetland Resources.

Guo, L., Coleman, C. H. Jr., \& Santschi, P. H. (1994). The distribution of colloidal and dissolved organic carbon in the Gulf of Mexico. Marine Chemistry, 45(1-2), 105-119.

Happ, G., Gosselink, J. G., \& Day, J. W. Jr. (1977). The seasonal distribution of organic carbon in a Louisiana estuary. Estuarine and Coastal Marine Science, 5(6), 695-705.

Harris, D., Horwáth, W. R., \& Van Kessel, C. (2001). Acid fumigation of soils to remove carbonates prior to total organic carbon or carbon-13 isotopic analysis. Soil Science Society of America Journal, 65(6), 1853-1856. https://doi.org/10.1016/j.marchem.2009.11.003

Hedges, J. I., \& Ertel, J. R. (1982). Characterization of lignin by gas capillary chromatography of cupric oxide oxidation products. Analytical Chemistry, 54(2), 174-178.

Hedges, J. I., and D. C. Mann (1979), The characterization of plant tissues by their lignin oxidation products, Geochimica et Cosmochimica Acta, 43(11), 1803-1807. https://doi.org/10.1016/0016-7037(79)90028-0

Henry, K. M., \& Twilley, R. R. (2013). Soil development in a coastal Louisiana wetland during a climate-induced vegetation shift from salt marsh to mangrove. Journal of Coastal Research, 29(6), 1273-1283.

Huang, W. (2010). Hydrodynamic modeling and ecohydrological analysis of river inflow effects on Apalachicola Bay, Florida, USA. Estuarine, Coastal and Shelf Science, 86(3), 526-534. https://doi.org/10.1016/j.ecss.2009.07.032

Jones, D. (2012). The Fathom Toolbox for Matlab: Multivariate ecological and oceanographic data analysis. College of Marine Science, University of South Florida, St. Petersburg, Florida, USA. Fathom Toolbox for Matlab website, Petersburg, FL.

Joshi, I. D., D'Sa, E. J., Osburn, C. L., \& Bianchi, T. S. (2017). Turbidity in Apalachicola Bay, Florida from Landsat 5 TM and field data: Seasonal patterns and response to extreme events. Remote Sensing, 9(4), 367. https://doi.org/10.3390/rs9040367

Joshi, I. D., D'Sa, E. J., Osburn, C. L., Bianchi, T. S., Ko, D. S., Oviedo-Vargas, D., et al. (2017). Assessing chromophoric dissolved organic matter (CDOM) distribution, stocks, and fluxes in Apalachicola Bay using combined field, VIIRS ocean color, and model observations. Remote sensing of environment, 191, 359-372. https://doi.org/10.1016/j.rse.2017.01.039

Keil, R. G., \& Neibauer, J. A. (2009). Analysis of cooking spices in natural waters. Limnology and Oceanography: Methods, 7(12), 848-855.

Kemp, M. W., \& Boynton, W. R. (1984). Spatial and temporal coupling of nutrient inputs to estuarine primary production: The role of particulate transport and decomposition. Bulletin of Marine Science, 35(3), 522-535.

Liu, B., D'Sa, E. J., \& Joshi, I. (2019). Multi-decadal trends and influences on dissolved organic carbon distribution in the Barataria Basin Louisiana from in-situ and Landsat/MODIS observations, Remote Sensing of Environment, 228, 183-202.

Liu, X., \& Huang, W. (2009). Modeling sediment resuspension and transport induced by storm wind in Apalachicola Bay, USA. Environmental Modelling \& Software, 24(11), 1302-1313. https://doi.org/10.1016/j.envsoft.2009.04.006

Livingston, R. J. (1984). Trophic response of fishes to habitat variability in coastal seagrass systems. Ecology, 65(4), 1258-1275. https://doi. org/10.2307/1938332

Livingston, R. J. (2013). Gulf of Mexico origin, waters, and biota: Volume 4, Ecosystem-based management. Texas A\&M University Press.

Louchouarn, P., Amon, R. M., Duan, S., Pondell, C., Seward, S. M., \& White, N. (2010). Analysis of lignin-derived phenols in standard reference materials and ocean dissolved organic matter by gas chromatography/tandem mass spectrometry. Marine Chemistry, 118(1-2), 85-97. https://doi.org/10.1016/j.marchem.2009.11.003

Mattraw, H. C., \& Elder, J. F. (1984). Nutrient and detritus transport in the Apalachicola River. FloridaRep: USGPO.

Meeter, D. A., Livingston, R. J., \& Woodsum, G. C. (1979). Long-term climatological cycles and population changes in a river-dominated estuarine system, in Ecological processes in coastal and marine systems (pp. 315-338). Boston; MA Springer.

Metzger, E. J., Smedstad, O. M., Thoppil, P. G., Hurlburt, H. E., Cummings, J. A., Wallcraft, A. J., et al. (2014). US Navy operational global ocean and Arctic ice prediction systems. Oceanography, 27(3), 32-43. https://doi.org/10.5670/oceanog.2014.66

Moran, M. A., \& Hodson, R. E. (1990). Contributions of degrading Spartina alterniflora lignocellulose to the dissolved organic carbon pool of a salt marsh, Marine ecology progress series. Oldendorf, 62(1), 161-168.

Mortazavi, B., Iverson, R. L., Huang, W., Lewis, F. G., \& Caffrey, J. M. (2000). Nitrogen budget of Apalachicola Bay, a bar-built estuary in the northeastern Gulf of Mexico. Marine Ecology Progress Series, 195, 1-14.

Najjar, R. G., Herrmann, M., Alexander, R., Boyer, E. W., Burdige, D. J., Butman, D., et al. (2018). Carbon budget of tidal wetlands, estuaries, and shelf waters of eastern North America. Global Biogeochemical Cycles, 32(3), 389-416. https://doi.org/10.1002/ 2017GB005790

Noreen, E. W. (1989). Computer-intensive methods for testing hypotheses. New York: Wiley. 
Osburn, C. L., Mikan, M. P., Etheridge, J. R., Burchell, M. R., \& Birgand, F. (2015). Seasonal variation in the quality of dissolved and particulate organic matter exchanged between a salt marsh and its adjacent estuary. Journal of Geophysical Research: Biogeosciences, 120, 1430-1449. https://doi.org/10.1002/2014JG002897

Osburn, C. L., \& St Jean, G. (2007). The use of wet chemical oxidation with high-amplification isotope ratio mass spectrometry (WCOIRMS) to measure stable isotope values of dissolved organic carbon in seawater. Limnology and Oceanography: Methods, 5(10), 296-308. https://doi.org/10.4319/lom.2007.5.296

Park, D. (2002). Hydrodynamics and freshwater diversion within Barataria Basin.

Penland, S., Connor, P. F. Jr., Beall, A., Fearnley, S., \& Williams, S. J. (2005). Changes in Louisiana's shoreline: 1855-2002. Journal of Coastal Research, 7-39.

Reed, D. J. (1989). Patterns of sediment deposition in subsiding coastal salt marshes, Terrebonne Bay, Louisiana: The role of winter storms Estuaries, 12(4), 222-227.

Sampere, T. P., Bianchi, T. S., Wakeham, S. G., \& Allison, M. A. (2008). Sources of organic matter in surface sediments of the Louisiana Continental margin: effects of major depositional/transport pathways and Hurricane Ivan. Continental Shelf Research, 28(17), $2472-2487$. https://doi.org/10.1016/j.csr.2008.06.009

Solis, R., \& Powell, G. (1999). Hydrography, mixing characteristics, and residence times of Gulf of Mexico estuaries. Biogeochemistry of Gulf of Mexico estuaries. New York, NY: John Wiley \& Sons.

Tebaldi, C., Strauss, B. H., \& Zervas, C. E. (2012). Modelling sea level rise impacts on storm surges along US coasts. Environmental Research Letters, 7(1), 014032.

Turner, R. E. (2011). Beneath the salt marsh canopy: Loss of soil strength with increasing nutrient loads. Estuaries and Coasts, 34(5), 1084-1093.

Turner, R. E., Baustian, J. J., Swenson, E. M., \& Spicer, J. S. (2006). Wetland sedimentation from Hurricanes Katrina and Rita. Science, 314(5798), 449-452.

Twilley, R. R. (1985), The exchange of organic carbon in basin mangrove forests in a southwest Florida estuary, Estuarine, Coastal and shelf science, 20(5), 543-557. https://doi.org/10.1016/0272-7714(85)90106-4

Tzortziou, M., Neale, P. J., Megonigal, J. P., Pow, C. L., \& Butterworth, M. (2011). Spatial gradients in dissolved carbon due to tidal marsh outwelling into a Chesapeake Bay estuary. Marine Ecology Progress Series, 426, 41-56.

Tzortziou, M., Neale, P. J., Osburn, C. L., Megonigal, J. P., Maie, N., \& Jaffé, R. (2008). Tidal marshes as a source of optically and chemically distinctive colored dissolved organic matter in the Chesapeake Bay. Limnology and Oceanography, 53(1), 148-159.

Visser, J. M., Sasser, C. E., Chabreck, R. H., \& Linscombe, R. (1998). Marsh vegetation types of the Mississippi River deltaic plain. Estuaries, 21(4), 818-828.

Wilson, C. A., \& Allison, M. A. (2008). An equilibrium profile model for retreating marsh shorelines in southeast Louisiana. Estuarine, Coastal and Shelf Science, 80(4), 483-494. https://doi.org/10.1016/j.ecss.2008.09.004

Wissel, B., A. Gaçe, and B. Fry (2005), Tracing river influences on phytoplankton dynamics in two Louisiana estuaries, Ecology, 86(10), 2751-2762. https://doi.org/10.1890/04-1714 